\title{
Palaeoecological analysis of maximum flooding zones from the Tithonian (Upper Jurassic) of the Kachchh Basin, western India
}

\author{
Franz T. Fürsich ${ }^{1}$. Matthias Alberti ${ }^{2} \cdot$ Dhirendra K. Pandey $^{3}$
}

Received: 3 August 2020 / Accepted: 13 November 2020 / Published online: 24 December 2020

(c) The Author(s) 2020

\begin{abstract}
The siliciclastic Jhuran Formation of the Kachchh Basin, a rift basin bordering the Malagasy Seaway, documents the filling of the basin during the late syn-rift stage. The marine, more than 700-m-thick Tithonian part of the succession in the western part of the basin is composed of highly asymmetric transgressive-regressive cycles and is nearly unfossiliferous except for two intervals, the Lower Tithonian Hildoglochiceras Bed (HB) and the upper Lower Tithonian to lowermost Cretaceous Green Ammonite Beds (GAB). Both horizons represent maximum flooding zones (MFZ) and contain a rich fauna composed of ammonites and benthic macroinvertebrates. Within the HB the benthic assemblages change, concomitant with an increase in the carbonate content, from the predominantly infaunal "Lucina" rotundata to the epifaunal Actinostreon marshii and finally to the partly epifaunal, partly infaunal Eoseebachia sowerbyana assemblage. The Green Ammonite Beds are composed of three highly ferruginous beds, which are the MFZ of transgressive-regressive cycles forming the MFZ of a 3rd-order depositional sequence. The GAB are highly ferruginous, containing berthieroid ooids and grains. GAB I is characterized by the reworked Gryphaea moondanensis assemblage, GAB II by an autochthonous high-diversity assemblage dominated by the brachiopods Acanthorhynchia multistriata and Somalithyris lakhaparensis, whereas GAB III is devoid of fossils except for scarce ammonites. The GAB are interpreted to occupy different positions along an onshore-offshore transect with increasing condensation offshore. Integrated analyses of sedimentological, taphonomic, and palaeoecological data allow to reconstruct, in detail, the sequence stratigraphic architecture of sedimentary successions and to evaluate their degree of faunal condensation.
\end{abstract}

Keywords Shell concentration $\cdot$ Sequence stratigraphy $\cdot$ Faunal condensation $\cdot$ Benthic macrofauna $\cdot$ Palaeoecology

Franz T. Fürsich

franz.fuersich@fau.de

Matthias Alberti

matthias.alberti@ifg.uni-kiel.de

Dhirendra K. Pandey

dhirendrap@ hotmail.com

1 FG Paläoumwelt, GeoZentrum Nordbayern der FriedrichAlexander-Universität Erlangen-Nürnberg, Loewenichstrasse 28, 91054 Erlangen, Germany

2 Institut für Geowissenschaften, Christian-Albrechts-Universit ät zu Kiel, Ludewig-Meyn-Strasse 10, 24118 Kiel, Germany

3 Department of Geology, School of Earth, Biological and Environmental Science, Central University of South Bihar, SH 7, Gaya-Panchanpur Road, Village Karhara, Post Fatehpur, Gaya, Bihar 824236, India

\section{Introduction}

In sequence stratigraphic terminology, a maximum flooding surface/zone is marking the end of shoreline transgression (Catuneanu 2006), i.e., it marks the position of the seafloor furthest away from the coastline during a cycle of fluctuating sea level. As a result, the sediments deposited in these areas are generally characterized by a comparatively small grain size, a reduced siliciclastic influx, commonly associated with the formation of synsedimentary iron minerals such as glauconite, which are thought to be the result of submarine weathering (Heim 1934; Odin and Matter 1981). Compared to beds above and below, such sediments are often condensed, that is they represent environments and organisms telescoped into a comparatively thin sediment unit (Föllmi 2016). In particular, fossil relicts preserved in such beds are excellent tools to identify their nature. They 
provide biostratigraphic evidence, for example when in extreme cases ammonites representing different zones are preserved side by side (e.g., Wendt 1970), but also their taphonomic and palaeoecological traits may supply critical information (e.g., Kidwell 1989, 1991; Kidwell and Bosence 1991; Abbott 1997; Brett 1998; Fürsich and Pandey 2003; Archuby and Fürsich 2010). The present paper focuses on the latter features in an attempt to explore their environmental and sequence stratigraphic significance. The two examples from the Tithonian part of the Jhuran Formation of the Kachchh Basin are rich in ammonites and benthic macrofauna. In this respect, they drastically differ from the remaining part of the formation in the study area, in which ammonites and any benthic macrofauna are scarce. Discussing the common features of, and the differences between, the two examples and combining them with the ichnological and sedimentological evidence leads to a precise characterization of maximum flooding zones exhibiting typical condensation features in comparatively shallow shelf positions.

\section{Geological overview and stratigraphy}

The Kachchh Basin is a small E-W oriented pericratonic rift basin at the western margin of the Indian Plate, facing the so-called Malagasy Gulf and filled with an at least 3000-m-thick Upper Triassic to Lower Cretaceous sediment package (e.g., Biswas 1980, 2016). The basin started to form in the Triassic when red beds were deposited. During the Early Jurassic, the sea advanced into the basin several times, documented by Pliensbachian and Toarcian marine nannofossils occurring reworked in younger beds (Rai and Jain 2013) and by marine to brackish bivalves, gastropods, and corals intercalated between non-marine coastal plain deposits (Pandey et al. 2002; Fürsich et al. 2013). From the Bajocian onwards, shallow marine conditions prevailed at least in the central parts of the basin (exposed in several domal structures of the so-called Kachchh Mainland) and persisted until the early Cretaceous (Fürsich et al. 2020). By that time much of the basin had become infilled with predominantly siliciclastic sediments prograding mainly from the east (e.g., Alberti et al. 2019), to a lesser extent also from the north.

The two fossil-rich units at the focus of this study occur in the western part of the basin (Fig. 1), in the Tithonian part of the Jhuran Formation as is evidenced by ammonites. The Kimmeridgian-Lower Cretaceous Jhuran Formation (formerly called Katrol and Umia formations) is a siliciclastic unit, the marine character of which increases from east to west towards the Malagasy Gulf. The Jurassic part of the formation comprises several members (Fig. 2).

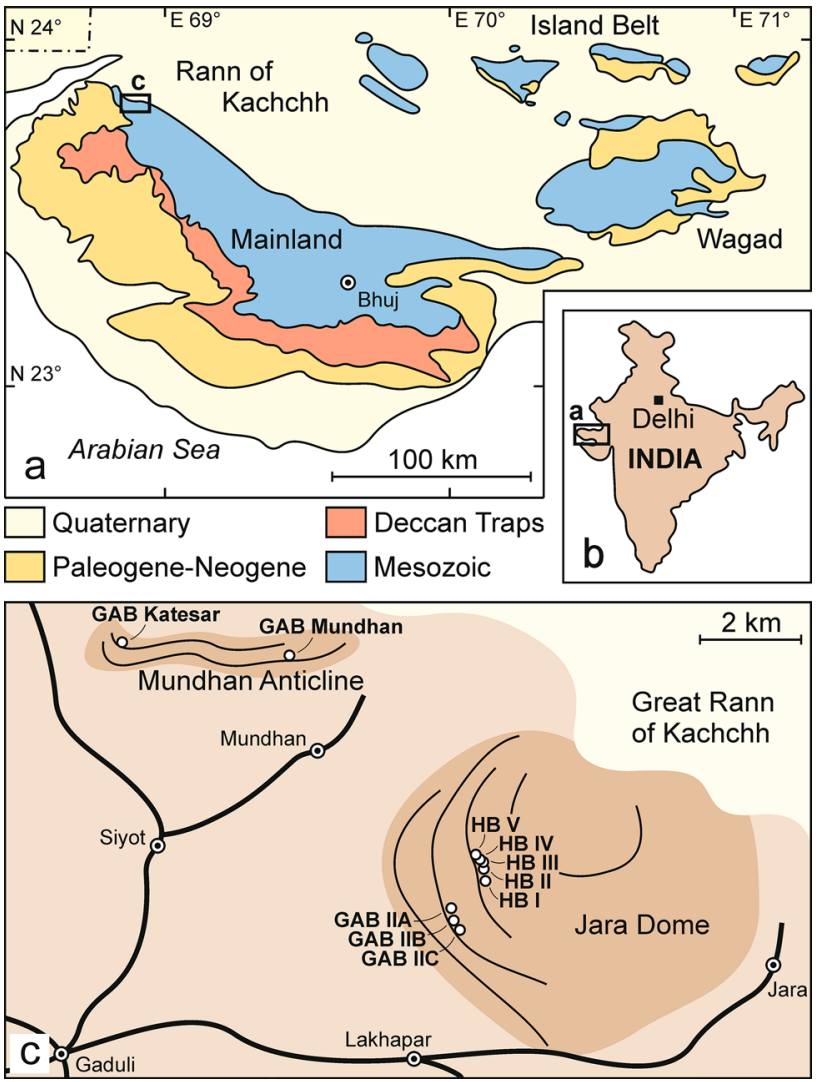

Fig. 1 a Simplified geological map of Kachchh, Gujarat. b Sketch of India. The rectangle denotes the area covered in (a). c Positions of the localities of the Hildoglochiceras Bed (HB I-V) and of the Green Ammonite Beds north of Lakhapar village (GAB I and GAB IIA to C), north of Mundhan village, and east of Katesar temple. The position of GAB I is the same as that of GAB IIB

These members differ from those proposed by Biswas (1980), because they allow a better characterization of the sedimentary succession but still await formal description (Fürsich et al., in prep.). The lower of the two condensed units, the so-called Hildoglochiceras Bed, is Early Tithonian in age (Pandey et al., submitted) and occurs in the informal Shivparas Siltstone member. The upper unit, the Green Ammonite Beds, forms most of the Umia Ammonite member and is late Early Tithonian to early Berriasian in age. Due to its high fossil content and wide lateral extension, it is a distinct marker bed and has been known since the late nineteenth century. The Hildoglochiceras Bed, in contrast, has only recently been discovered. It is characterized by a high carbonate content, which is unique in the Jhuran Formation, whereas the Green Ammonite Beds are rich in iron minerals such as berthieroid ooids and grains. The most outstanding feature of the two units is their rich benthic macrofauna in contrast to the rest of the Jhuran Formation. 


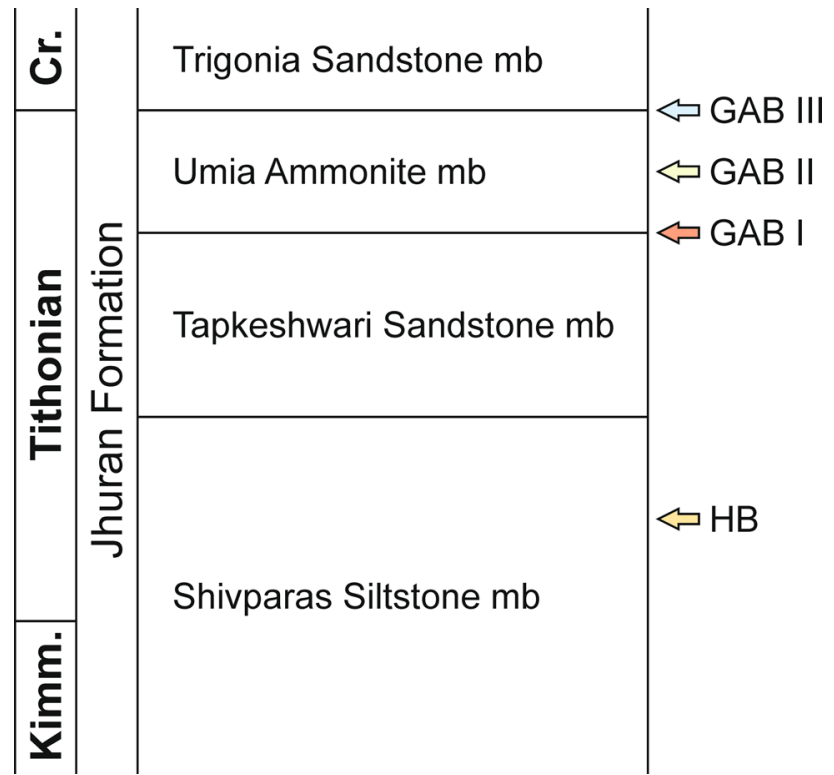

Fig. 2 Tithonian lithostratigraphy of the western Kachchh Basin with positions of the Hildoglochiceras Bed (HB) and the Green Ammonite Beds (GAB I-III). Note that the names of members are still informal (Fürsich et al. in prep.). Cr., Cretaceous

Table 1 Coordinates of the Hildoglochiceras Bed and the Green Ammonite Beds in the northwestern Kachchh Basin

\begin{tabular}{|c|c|c|}
\hline \multicolumn{3}{|l|}{ Hildoglochiceras Bed } \\
\hline HB I & $\mathrm{N} 23^{\circ} 43^{\prime} 35^{\prime \prime}$ & E68 $57^{\prime} 55.1^{\prime \prime}$ \\
\hline HB II & $\mathrm{N} 23^{\circ} 43^{\prime} 43^{\prime \prime}$ & E68 $57^{\prime} 54^{\prime \prime}$ \\
\hline HB III & $\mathrm{N} 23^{\circ} 43^{\prime} 46.7^{\prime \prime}$ & E68 $57^{\prime} 53.7^{\prime \prime}$ \\
\hline HB IV & $\mathrm{N} 23^{\circ} 43^{\prime} 47.8^{\prime \prime}$ & $\mathrm{E} 68^{\circ} 57^{\prime} 51.3^{\prime \prime}$ \\
\hline HB V & $\mathrm{N} 23^{\circ} 43^{\prime} 49^{\prime \prime}$ & $\mathrm{E} 68^{\circ} 57^{\prime} 50^{\prime \prime}$ \\
\hline \multicolumn{3}{|c|}{ Green Ammonite Beds } \\
\hline GAB IIA & $\mathrm{N} 23^{\circ} 43^{\prime} 17.4^{\prime \prime}$ & E68 $57^{\prime} 32.6^{\prime \prime}$ \\
\hline GAB IIB, GAB I & $\mathrm{N} 23^{\circ} 43^{\prime} 08.8^{\prime \prime}$ & $\mathrm{E} 68^{\circ} 57^{\prime} 32.1^{\prime \prime}$ \\
\hline GAB IIC & $\mathrm{N} 23^{\circ} 43^{\prime} 04.5^{\prime \prime}$ & E68 $57^{\prime} 35.4^{\prime \prime}$ \\
\hline GAB Mundhan & $\mathrm{N} 23^{\circ} 46^{\prime} 08.8^{\prime \prime}$ & $\mathrm{E} 68^{\circ} 55^{\prime} 38.2^{\prime \prime}$ \\
\hline GAB Katesar & $\mathrm{N} 23^{\circ} 46^{\prime} 18.8^{\prime \prime}$ & $\mathrm{E} 68^{\circ} 53^{\prime} 35.1^{\prime \prime}$ \\
\hline
\end{tabular}

\section{Materials and methods}

Detailed sections have been measured through the Hildoglochiceras Bed (HB) in the SW part of the Jara Dome (Fig. 1). The horizon, which laterally could be traced for $470 \mathrm{~m}$, has been repeatedly sampled at five localities (Table 1). Outcrop conditions are poor due to the recessive nature of the bed and the presence of some faults (Fig. 3a). For this reason, sections could be measured only at two of the localities. Moreover, no levels within the bed could be sampled at high resolution, and all material collected was weathered out from the largely unconsolidated rock so that a certain degree of artificial time-averaging could not be avoided. Statistical collections could be made at localities HB I-III, whereas at localities IV and V the abundance of taxa was evaluated semi-quantitatively in four categories (r, rare; o, occurring; c, common, and a, abundant), as the number of specimens was too low to be statistically meaningful.

In the case of the Green Ammonite Beds (GAB) outcrop conditions were very good (Fig. 3b). The GAB consist of three beds (I-III), separated by argillaceous-silty interbeds. The uppermost one is unfossiliferous except for very rare ammonites so that only GAB I and II have been bulk-sampled. Sampling of the benthic macrofauna involved counting in the field and identification of fossils in the laboratory, after the specimens had been cleaned and mechanically prepared. Lithological information obtained in the field was supported by the study of thin-sections under the binocular microscope. In the case of bivalves and brachiopods, the number of individuals has been calculated by adding to the number of articulated shells the number of right/pedicle valves as opposed to left/brachial valves (whichever number was larger), and the number of single valves divided by two. Shell-encrusting serpulids have been counted as one individual per shell and the few decapod claws, echinoid plates, and crinoid ossicles have also been counted as a single individual each.

\section{Features of the two maximum flooding zones}

\section{The Hildoglochiceras Bed}

\section{Lithological features}

The Hildoglochiceras Bed is the only carbonate-rich horizon within the 715-m-thick siliciclastic Kimmeridgian to Lower Cretaceous Jhuran Formation. It occurs $357 \mathrm{~m}$ above the base of the formation (Fig. 4), has a thickness of $1.5 \mathrm{~m}$ (Fig. 4), and can be traced for about $470 \mathrm{~m}$ along strike. It forms the top of a 12-m-thick coarse-grained sandstone with remains of large-scale trough stratification and encompasses also an overlying 1-m-thick sandy bioclastic marl unit. The upper boundary of the bed is sharp. The lower boundary differs in character between the two sections (HB I and II), where it could be measured. In HB I its base has been placed at a very irregular ferruginous crust that exhibits a pronounced relief reminiscent of a karst topography but the lithology of the rock below this crust does not drastically differ from that above (Figs. 4, 5a). Within decimetre-deep narrow cavities, traced by the ferruginous crust, vertically arranged elongated wood pieces are found, 

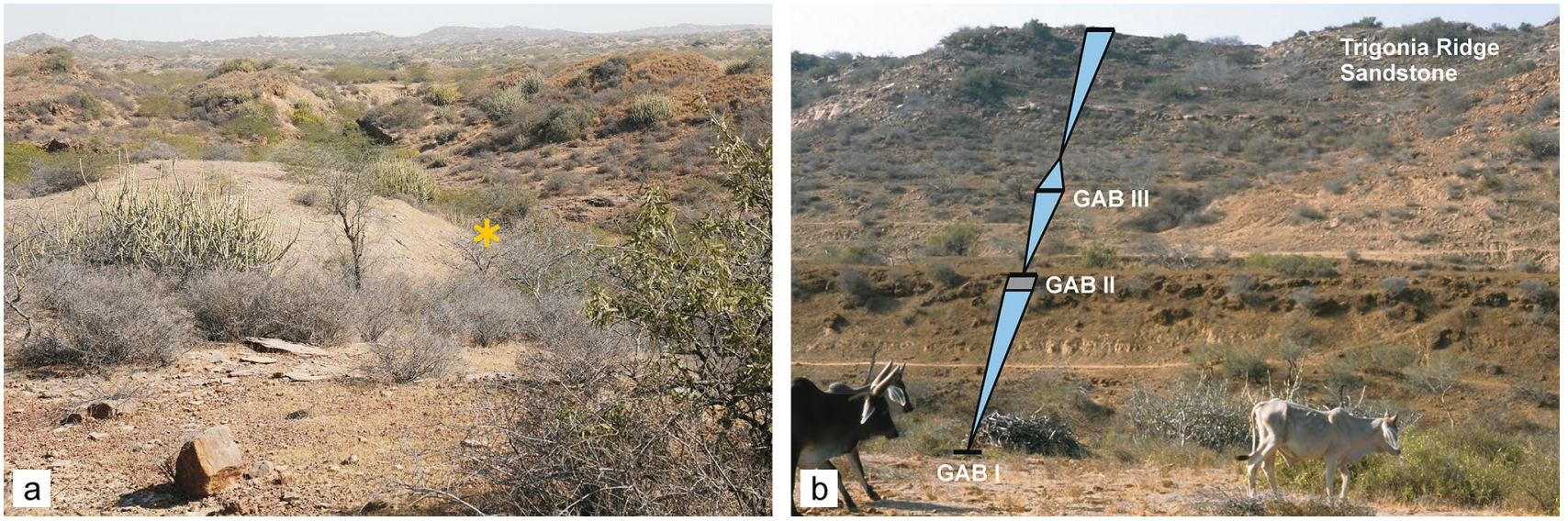

Fig. 3 Field photographs of (a) the Hildoglochiceras Bed (marked with an asterisk) and (b) the Green Ammonite Beds north of Lakhapar. The photograph in (b) was taken more than 20 years ago. At present much of the area is covered by dense thorny shrubs

which indicate that the ferruginous crust is not a diagenetic but a primary feature. At locality HB II, the base of the bed has been drawn at the top of a 2-m-thick decalcified ferruginous medium-grained sandstone (Fig. 4), whereas its top is not exposed. The lateral extent of this emersion horizon could not be established due to faulting and poor outcrop conditions. In HB I, the light-grey sandy marl at the top is followed by dark-grey argillaceous silt with claret-coloured iron concretions.

Lithologically, the bed is composed of two parts; a lower part consisting of rubbly coarse-grained micritic sandstone and an upper part consisting of marl with numerous scattered fine to coarse quartz grains. Due to intense bioturbation, the boundary between the two parts is very diffuse, and the abundance of the coarse quartz grains decreases towards the top. The quartz grains are very poorly sorted (Fig. 6a). Large grains are subrounded to well rounded, whereas small grains are angular to subangular. Apart from quartz, grains rarely consist of rounded rock fragments (sandstones and metamorphic rocks). Bioclasts include bivalve and echinoderm fragments. In microfacies terms, the rock is a sandy bio-wacke to floatstone (sandy allochem limestone sensu Mount 1985). The lack of bedding planes and the irregular distribution of micrite and coarse quartz grains are signs that the HB has been thoroughly bioturbated, except possibly for its uppermost part (see below). Recognizable trace fossils include the crustacean burrows Thalassinoides in two size classes (1-1.5 cm and $2.5-3 \mathrm{~cm}$ in diameter) and fragments of Gyrolithes isp. In thin-sections, small (diameter 1-2 mm) oblique to subhorizontal cylindrical burrows filled with siltsized quartz grains and exhibiting a distinct backfill structure are common. Shells of ammonites, nautiloids and a number of benthic macroinvertebrates are common and represent a moderately diverse fauna. Wood fragments, up to $10 \mathrm{~cm}$ in length and commonly bored by the bivalve Turnus, occur locally. At HB I, the sandy bioclastic wackestone immediately below the ferruginous crust that forms the base of the Hildoglochiceras Bed is very similar in lithology but contains abundant $\mathrm{cm}$-sized irregular cavities filled with several generations of sparite (Fig. 6b, c).

\section{Age}

The age of the HB can be determined by the presence of ammonites (above all Hildoglochiceras kobelliforme (Bonarelli 1893) and H. kobelli (Oppel 1863); less common are Haploceras staszycii (Zeuschner 1846), Taramelliceratinae gen. and sp. indet., Aulacosphinctoides sp., and Virgatosphinctes s.l. Accordingly, the bed has been placed in the lower part of the Early Tithonian albertinum/darwini Zone (Pandey et al., submitted). The Hildoglochiceras Bed should not be confused with a Hildoglochiceras-bearing horizon described by Pandey et al. (2016), which occurs stratigraphically much higher in the Katesar section further west.

\section{Benthic macrofauna}

Taphonomic features The shelly macrobenthos of the HB is moderately well-preserved. Originally aragonitic shells of bivalves and gastropods are preserved in calcite, but some specimens lost their shell during weathering. Shell ornamentation is usually well-preserved, and signs of abrasion are rare. Infaunal bivalves and brachiopods are usually articulated, whereas the majority of epifaunal and endobyssate bivalves occur as single valves. The number of encrusted shells (2.5 to $14.1 \%$ ) and bored shells $(0.8$ and $2.1 \%$ ) is low (Fig. 7). Shell fragments are common but usually small. Large bivalve shells became mostly fragmented during weathering. 


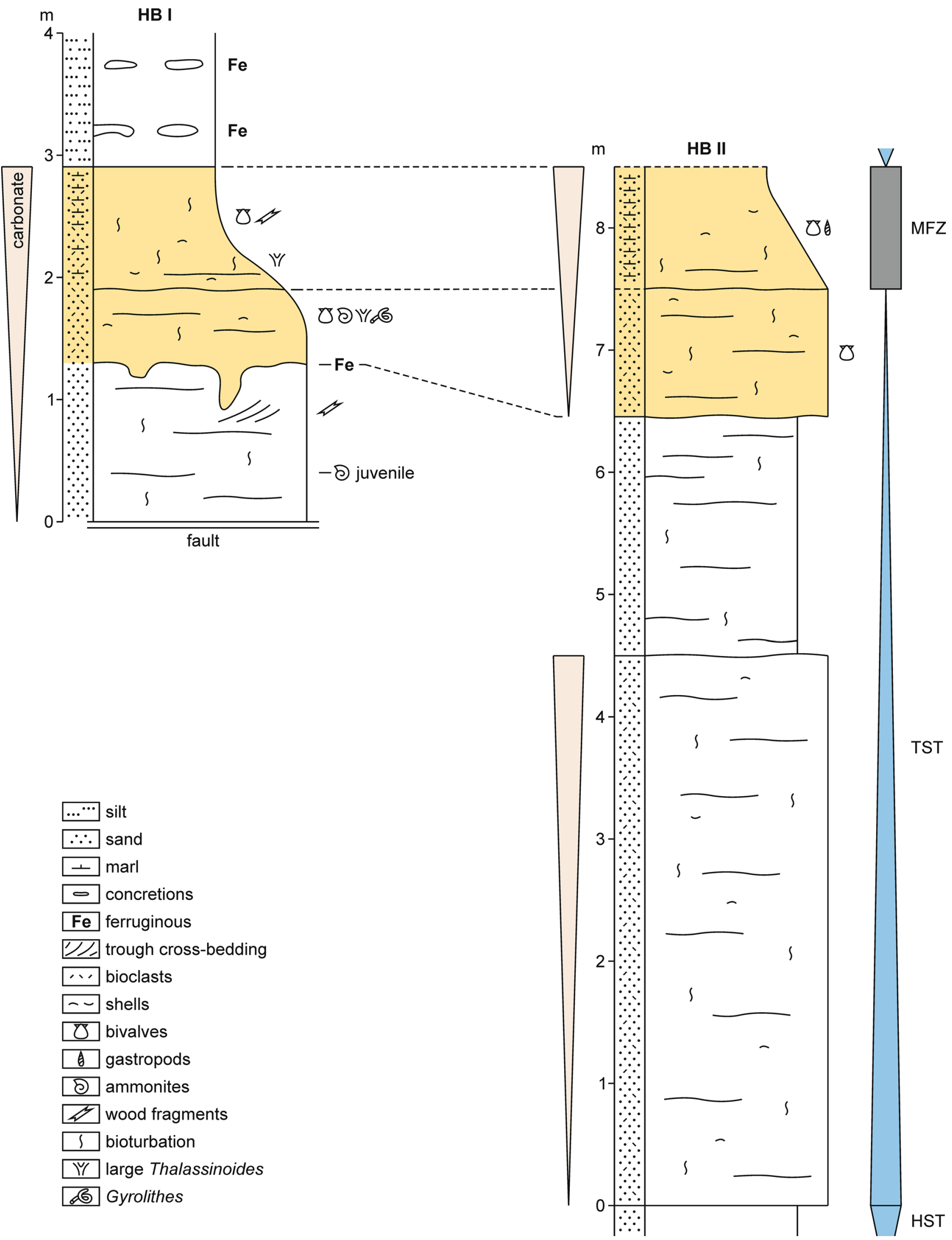

Fig. 4 Detailed sections through the Hildoglochiceras Bed at localities HB I and HB II and its sequence stratigraphic interpretation 

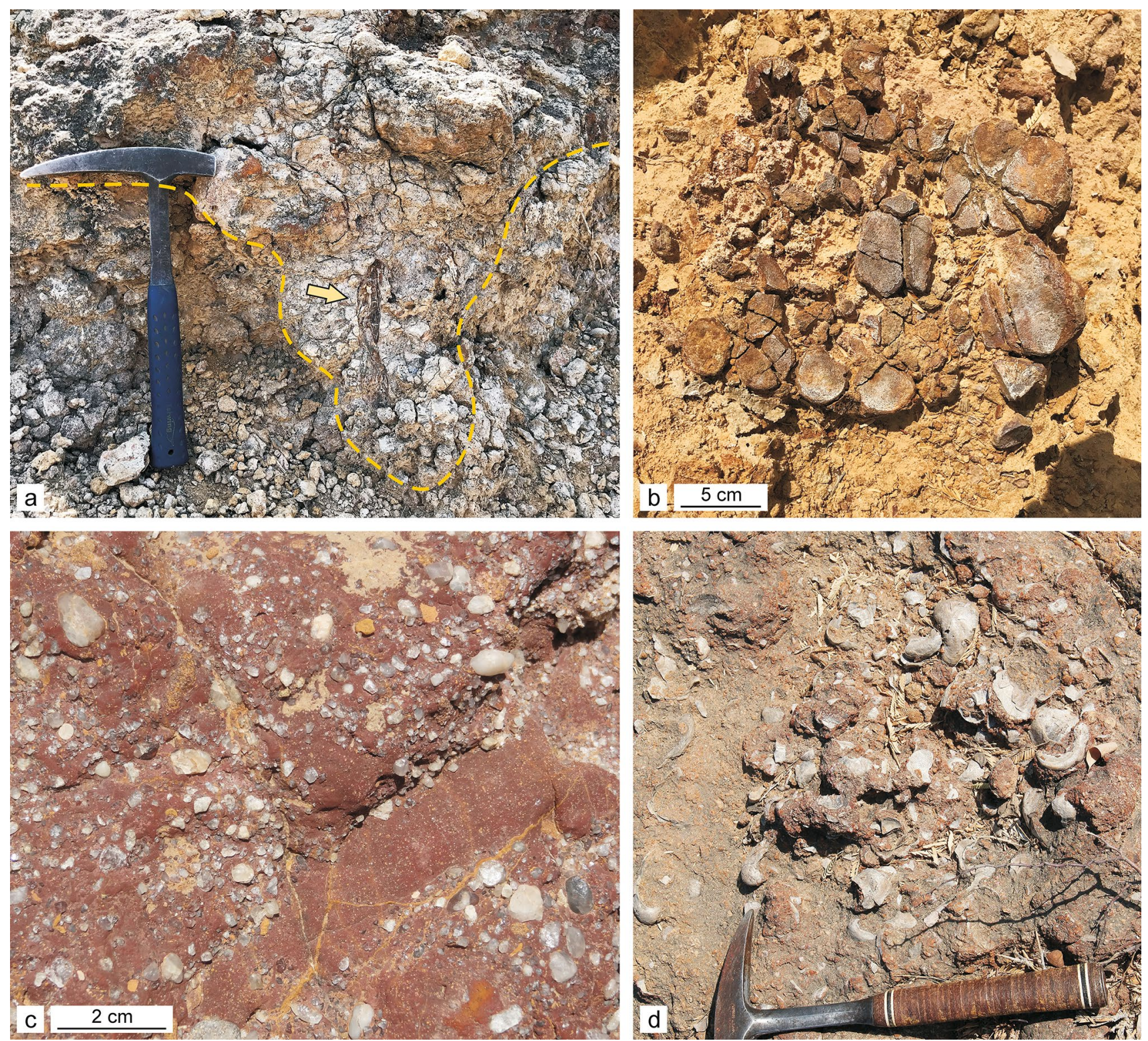

Fig. 5 Details of the Hildoglochiceras Bed (a, b) and the Green Ammonite Beds (c, d). a An iron crust (dashed line) traces the highly irregular lower boundary of the Hildoglochiceras Bed at locality HB I. Note the vertically arranged wood piece (arrowed) in a cavity filled with sediment of the Hildoglochiceras Bed. The boundary is interpreted as a karst surface, corresponding to a sequence boundary.

Faunal composition Bivalves are by far the dominant faunal element accounting for $84-96 \%$ of the individuals, followed by gastropods, serpulids, echinoids, crinoids, and calcisponges. They dominate also in terms of taxa constituting 47 of altogether 67 taxa (Fig. 7, Table 2). The fauna represents a variety of guilds such as epibyssate forms (e.g., Oxytoma, Chlamys, Spondylopecten, Megacucullaea), cemented forms (e.g., the oysters Nanogyra, Actinostreon, Liostrea, and serpulids), free recliners able to swim for short
Hammer for scale. b Flipper of an ?ichthyosaur; HB III. c Top surface of the Green Ammonite Bed I at Mundhan with scattered coarse quartz grains and granules. The burrow seen in the lower right quadrangle is probably Thalassinoides isp. d Lenticle of Gryphaea moondanensis; GAB I, Mundhan

distances (Entolium), endobyssate forms (e.g., Gervillella), shallow burrowers (trigoniids; e.g., Rhinetrigonia retrorsa, Fig. 8c), deep burrowers (e.g., 'Lucina', Pholadomya, Pleuromya), infaunal mobile (Rollieria) and epifaunal mobile forms (gastropods), and wood borers (Turnus) (Fig. 8b). In terms of trophic groups, suspension-feeders dominate (brachiopods, serpulids, sponges, crinoids, nearly all bivalves), but at locality HB I the likely chemosymbiotic 'Lucina' rotundata (Fig. 8d) accounts for more than half of all indi- 

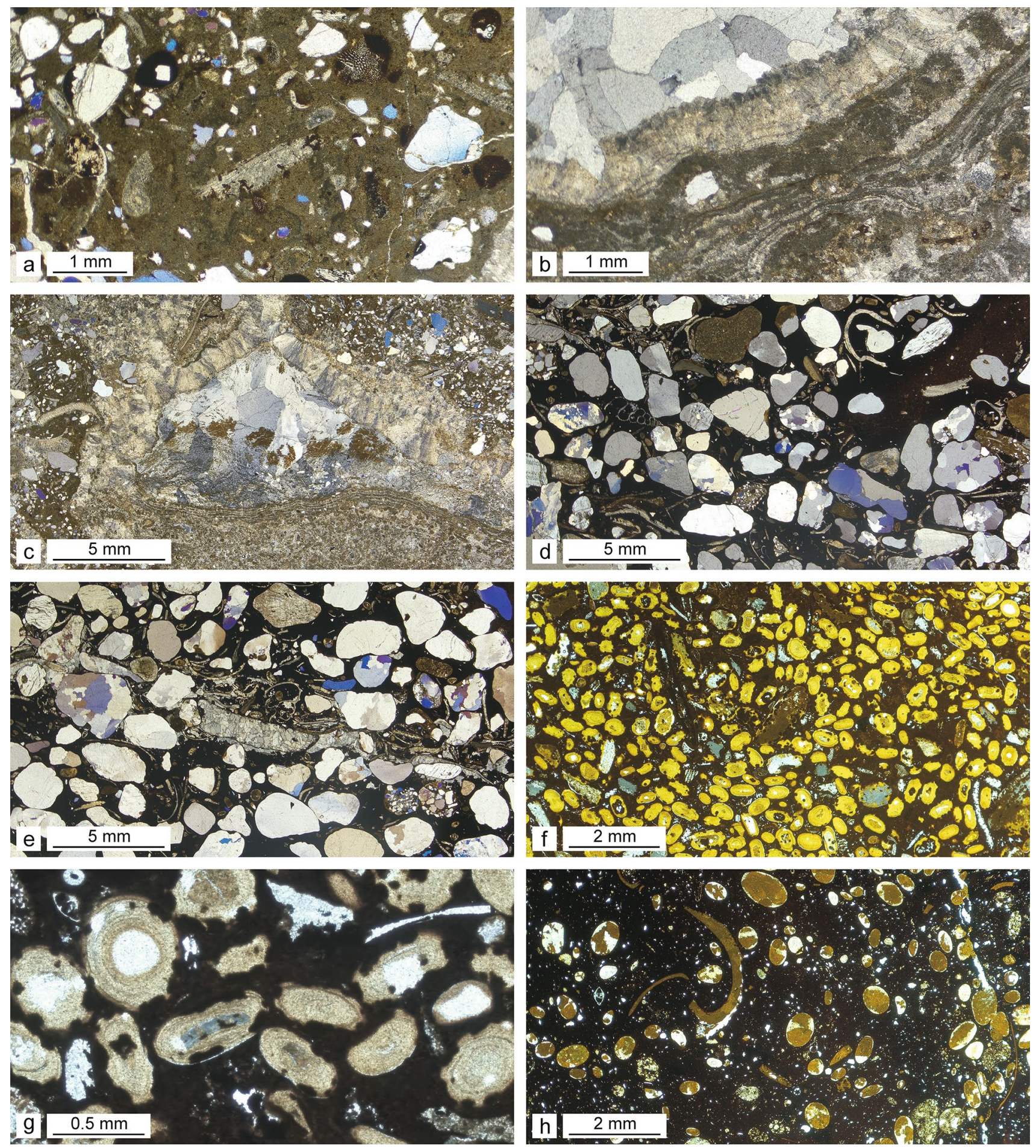

Fig. 6 Photomicrographs of the Hildoglochiceras Bed (a-c) and the Green Ammonite Beds (d-f). a Poorly sorted, sandy, bioclastic argillaceous wackestone with rare ferruginous grains, HB I. b, c Different cement generations filling a highly irregular cavity in the bed immediately underlying the Hildoglochiceras Bed, interpreted as dissolution cavities, HB I. d, e Coarse quartz grains and scattered rock fragments, partly grain-supported, partly floating in a ferruginous

bioclastic mudrock. GAB I, Lakhapar section. f, g Bioclastic wacketo packironstone with an oxyhydroxide mudrock matrix. Many of the berthieroid ooids are partly replaced by Fe-oxyhydroxide at their margins. Most bioclasts are of echinoderm or bivalve origin. GAB II, Lakhapar section. h Silty to fine-sandy mudrock with scattered berthieroid ooids and grains and ferruginized bioclasts. GAB II, Mundhan section 

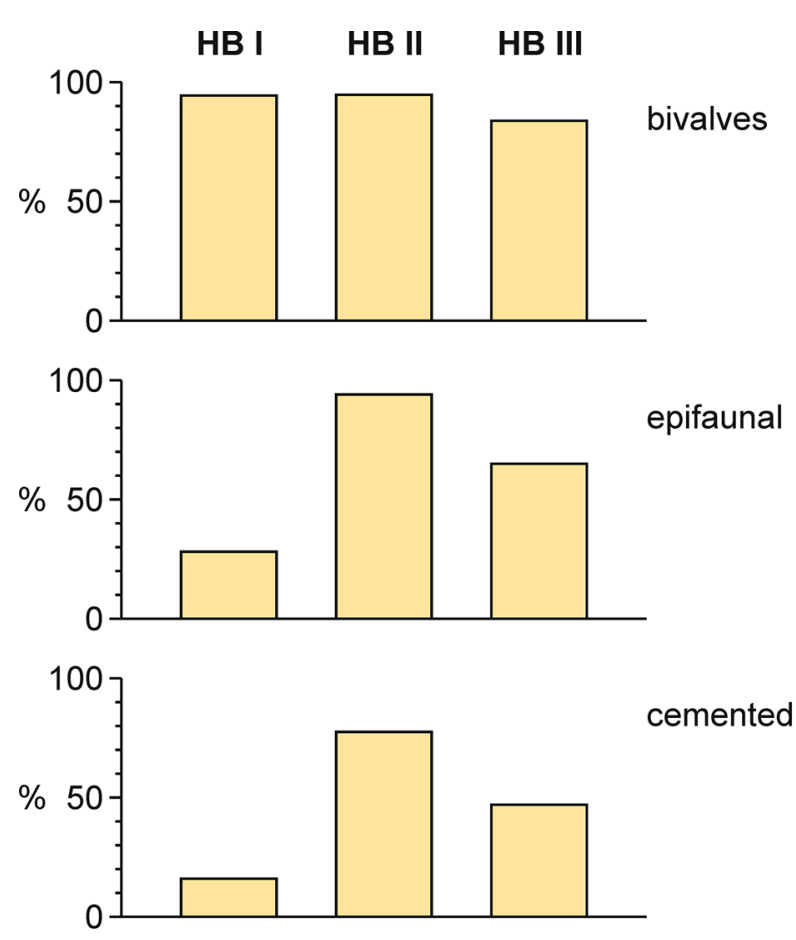

cemented

$\% 50$
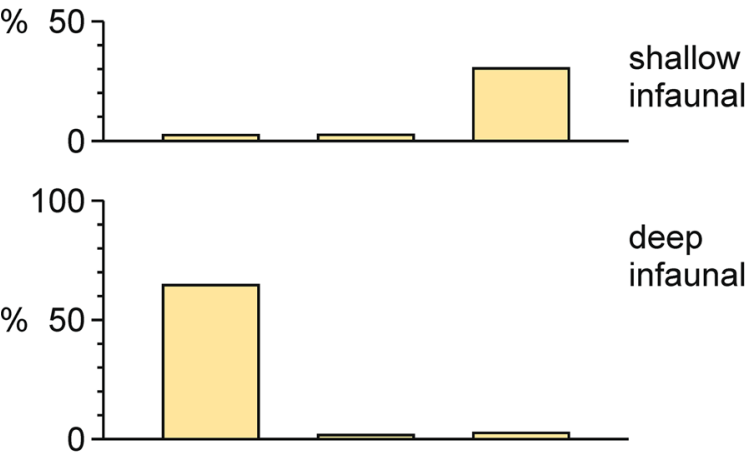

deep

infaunal

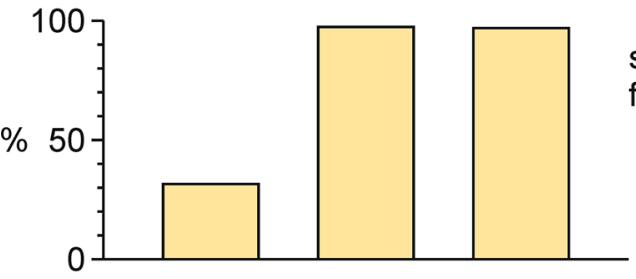

suspensionfeeding

$\%$

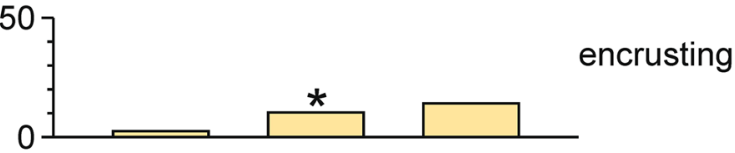

$\% 50$

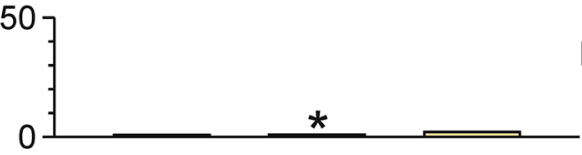

bored

Fig. 7 Ecological features (mode of life, trophic groups, encrustation, boring) of the benthic macrofauna of the Hildoglochieras Bed at localities HB I to III. The asterisks indicate that these values are most likely underestimations
Table 2 Taxonomic and guild composition of the Hildoglochiceras Bed

Trophic group Mode of life

Plants

Wood fragments

Nekton

Belemnites

Paracenoceras sp.

Haploceras elimatum (Oppel)

Haploceras deplanatum Waagen

Hildoglochiceras kobelli (Oppel)

Taramelliceratinae gen. et sp. indet

Virgatosphinctes s.l. sp.

Ichthyosaur rib fragments and vertebrae

Macrobenthos

Sponges

Calcisponge A

Calcisponge B

ec

Annelids

Serpula (Cycloserpula) cf. intesti- $\quad$ s $\quad$ ec nalis

Serpula (Cycloserpula) sp. $\quad$ s $\quad$ ec

Serpula (Dorsoserpula) sp. A $\quad$ s $\quad$ ec

Serpula (Dorsoserpula) sp. B $\quad$ s $\quad$ ec

Arthropods

Decapod claw

$\mathrm{sc}$

em

Gastropods

Bathrotomaria sp.

$\mathrm{h} / \mathrm{d} \quad \mathrm{em}$

Leptomaria sp.

Oolitica? sp.

Proconulus sp.

$\begin{array}{ll}\mathrm{h} / \mathrm{d} & \mathrm{em} \\ \mathrm{h} / \mathrm{d} & \mathrm{em}\end{array}$

Eucyclus sp.

$\begin{array}{ll}\mathrm{h} / \mathrm{d} & \mathrm{em} \\ \mathrm{h} / \mathrm{d} & \mathrm{em}\end{array}$

$\mathrm{h} / \mathrm{d} \quad \mathrm{em}$

Bivalves

Nuculana (Rollieria) meriani

Grammatodon (Gr.) sp.

Megacuccullaea eminens

$\mathrm{h} / \mathrm{d} \quad \mathrm{em}$

Meleagrinella echinata

Meleagrinella sp. A

Oxytoma inequivalve

Placunopsis fuersichi

Pinna sp.

Gervillella sp.

Spondylus (Spondylus) jumaraensis

Spondylopecten (Plesiopecten) subspinosus

Entolium corneolum

Chlamys textoria

Radulopecten fibrosus

Radulopecten moondanensis

Integricardium bannesianum

Nicaniella sp. $\mathrm{sb} / \mathrm{m}$

eb

$\mathrm{eb}$

$\mathrm{eb}$

eb

eb

ec

si

si

ec

eb

er

eb

eb

eb

sb

$\mathrm{sb}$ 
Table 2 (continued)

\begin{tabular}{|c|c|c|}
\hline & Trophic group & Mode of life \\
\hline Neocrassina compressa & $\mathrm{s}$ & $\mathrm{sb}$ \\
\hline Seebachia (Eoseebachia) sowerbyana & $\mathrm{s}$ & $\mathrm{sb}$ \\
\hline Seebachia (Eoseebachia) elongata & $\mathrm{s}$ & $\mathrm{sb}$ \\
\hline Inoperna khadirensis & s & si \\
\hline Inoperna perplicata & s & si \\
\hline Liostrea sp. A & $\mathrm{s}$ & $\mathrm{ec}$ \\
\hline Liostrea sp.B & s & $\mathrm{ec}$ \\
\hline Nanogyra nana & s & ec \\
\hline Praeexogyra sp. & s & ec \\
\hline “Rastellum” sp. & $\mathrm{s}$ & ec \\
\hline Actinostreon marshii & $\mathrm{s}$ & ec \\
\hline Ctenostreon proboscideum & $\mathrm{s}$ & $\mathrm{eb}$ \\
\hline Plagiostoma schimperi & $\mathrm{s}$ & $\mathrm{eb}$ \\
\hline Pseudolimea duplicata & $\mathrm{s}$ & eb \\
\hline "Lucina" rotundata & $\mathrm{c}$ & $\mathrm{db}$ \\
\hline Shallow-burrowing heterodont & $\mathrm{s}$ & $\mathrm{sb}$ \\
\hline Vaugonia (Orthotrigonia) sp. & s & $\mathrm{sb}$ \\
\hline Trigonia (Trigonia) sp. & s & $\mathrm{sb}$ \\
\hline Trigonia (Trigonia) tenuis & s & $\mathrm{sb}$ \\
\hline Frenguelliella $\mathrm{cf}$. kheraensis & s & $\mathrm{sb}$ \\
\hline Opisthotrigonia retrorsa & s & $\mathrm{sb}$ \\
\hline Turnus sp. & $\mathrm{d}$ & $w b$ \\
\hline ?Pachymya (Arcomya) sp. & $\mathrm{s}$ & $\mathrm{db}$ \\
\hline Pholadomya (Ph.) sp. A & $\mathrm{s}$ & $\mathrm{db}$ \\
\hline Pholadomya (Ph.) cf. inornata & $\mathrm{s}$ & $\mathrm{db}$ \\
\hline Pholadomya (Ph.) cf. aequalis & $\mathrm{s}$ & $\mathrm{db}$ \\
\hline Pholadomya (Bucardiomya) sp. & s & $\mathrm{db}$ \\
\hline Pleuromya uniformis & s & $\mathrm{db}$ \\
\hline ?Homomya sp. & $\mathrm{s}$ & $\mathrm{db}$ \\
\hline $\begin{array}{l}\text { Anomalodesmatan bivalve gen. et } \\
\text { sp. nov }\end{array}$ & $\mathrm{s}$ & $\mathrm{db}$ \\
\hline \multicolumn{3}{|l|}{ Brachiopods } \\
\hline Terebratulid & s & ep \\
\hline Rhynchonellid & $\mathrm{s}$ & ep \\
\hline \multicolumn{3}{|l|}{ Echinoderms } \\
\hline Cidaroid spines and plates & $\mathrm{h} / \mathrm{d}$ & em \\
\hline Pseudodiadema sp. & $\mathrm{h} / \mathrm{d}$ & $\mathrm{em}$ \\
\hline Rhabdocidaris sp. & $\mathrm{h} / \mathrm{d}$ & $\mathrm{em}$ \\
\hline Irregular echinoid & $\mathrm{h} / \mathrm{d}$ & $\mathrm{im}$ \\
\hline Pentacrinites sp. (ossicles) & $\mathrm{s}$ & ec \\
\hline Stemless crinoid calyx & $\mathrm{s}$ & $\mathrm{ec}$ \\
\hline
\end{tabular}

Mode of life: $e b$ epibyssate, $e c$ epifaunal, cemented, er epifaunal, reclining, ep epifaunal, pedicle attached, $w b$ wood-boring, si semiinfaunal, $s b$ shallow-burrowing, $d b$ deep-burrowing, em epifaunal, mobile, im infaunal, mobile. Trophic group: $s$ suspension-feeding, $d$ deposit-feeding, $h / d$ herbivorous/feeding on plant detritus, $s c$ scavenger, $c$ chemosymbiotic viduals. Mobile herbivores/detritus feeders are represented by gastropods and echinoids, infaunal deposit feeders by the rare bivalve Rollieria and the scaphopod Laevidentalium. Several decapod claws indicate the presence of scavengers. The wood-boring Turnus was feeding on drift wood, constructing short tunnels (Fig. 8b).

Some shells are encrusted by the small oyster Nanogyra, whereas the large oyster Actinostreon marshii (Fig. 8a) encrusted shells of the same species (auto-encruster), commonly forming small clusters. Only few shells are bored by acrothoracican barnacles (Rogerella isp.), phoronids (Talpina isp.), and an unknown organism producing small cylindrical holes (Oichnus isp.).

Lateral and vertical faunal changes Considering that the $\mathrm{HB}$ could be followed for only half a kilometre and that the distance between sections ranges from 50 to $257 \mathrm{~m}$, the lateral changes in faunal composition and the relative abundance of taxa are quite striking. For example, 'Lucina' rotundata is quite abundant at locality HB I, rare at HB II and absent from HB III to V (Fig. 9). The large, plicate oyster Actinostreon marshii is the most abundant species at HB II, rare at HB I and occurring at HB III. The presence of the woodboring bivalve Turnus is tied to the presence of wood pieces, which are most abundant at HB I, III, and IV (Fig. 10).

Benthic assemblages The samples from the different localities do not represent the same level in the 1.5-m-thick bed, as exposures and weathering of the different levels varied along the outcrop belt. For example, the sample dominated by "Lucina" at HB I is from a lower level than those of the other localities, where the content of coarse quartz grains is lower and the marl content higher.

The "Lucina" rotundata assemblage is strongly dominated by the name-giving species, and infauna (more than $70 \%$ ) is, therefore, the dominant guild (Table 3). The species presumably was a deep-burrowing chemosymbiont like many other members of the family (e.g., Stanley 2014; Hryniewicz et al. 2020). They are nearly exclusively preserved as articulated specimens, and this is also true of other infaunal taxa such as Pholadomya and of the semi-infaunal Inoperna. This documents that they are at least parautochthonous, if not autochthonous. Only $28.1 \%$ of the individuals lived on the substrate such as the byssate bivalves Plesiopecten, Plagiostoma, Meleagrinella and small brachiopods, and $31.5 \%$ of the individuals were suspension-feeding. Large wood pieces are commonly bored by the bivalve Turnus (Fig. 8b). If this bivalve colonized the wood pieces, while they were still floating, it is not a member of the benthic community. Alternatively, Turnus could have bored the 


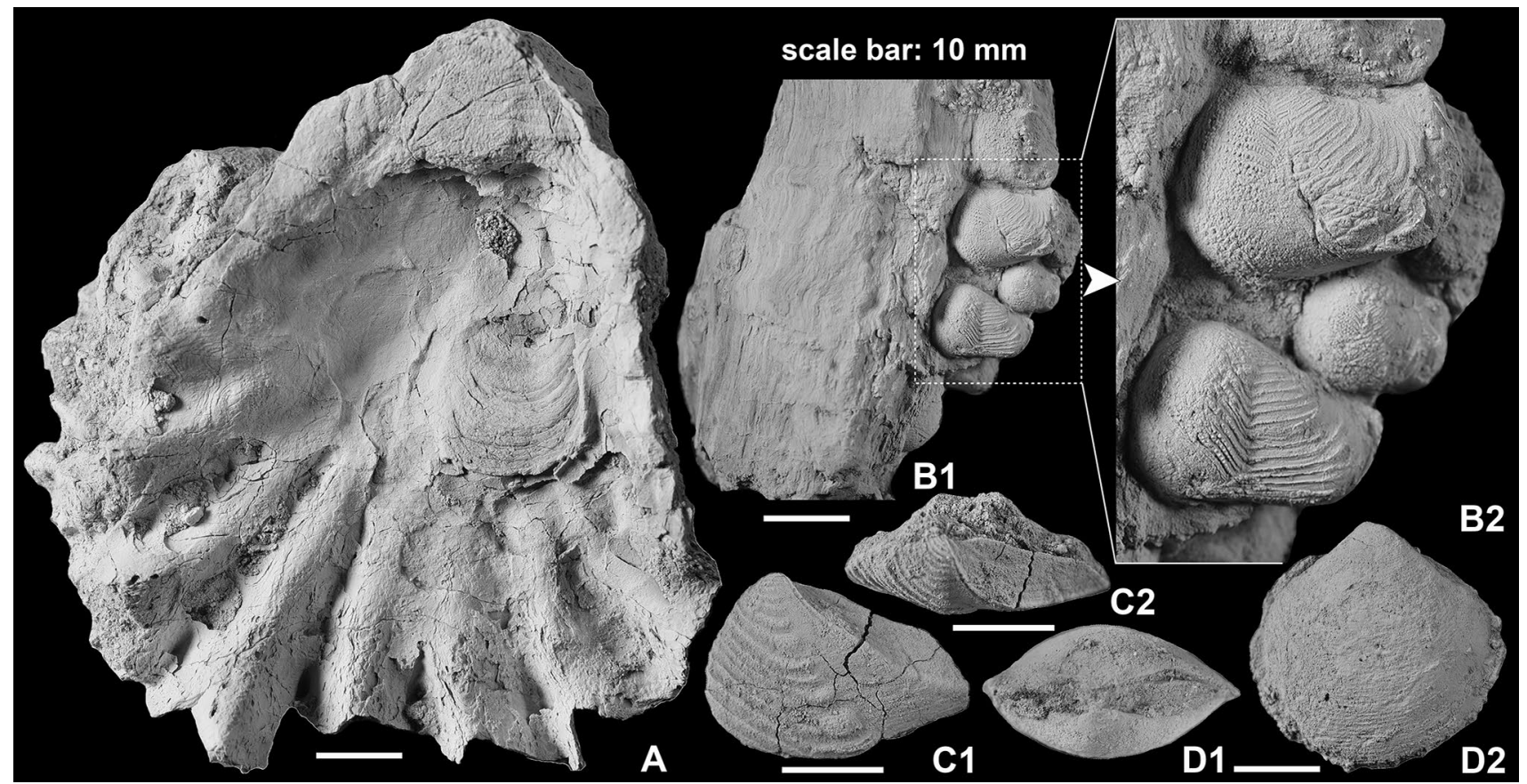

Fig. 8 Characteristic fossils of the Hildoglochiceras Bed. a Actinostreon marshii (J. Sowerby, 1820). b Turnus sp., boring in wood. c Rhinetrigonia retrorsa (Kitchin 1903). d "Lucina" rotundata (Roemer, 1836)

driftwood after it had settled on the sea floor. Which interpretation is correct cannot be decided. Due to the dominance of infaunal taxa and the small size of most epifaunal taxa, only few individuals have been bored $(0.8 \%)$ or encrusted (2.5\%) (Table 4).

At HB II, the oysters Actinostreon marshii (Fig. 8a), Nanogyra nana, and Liostrea sp. account for nearly threefourth of the individuals (Table 3). This Actinostreon marshii assemblage is strongly dominated by suspension-feeding cementing taxa $(77.5 \%)$, whereby the large Actinostreon forms small clusters, which are occasionally encrusted by Nanogyra. Epifauna accounts for 94\% (apart from the oysters, byssate forms such as Pseudolimea, Plagiostoma and Radulopecten), the rest consisting of occasional shallowburrowing (Eoseebachia, Protocardia) and rare deep-burrowing bivalves (Pholadomya). Only $10.3 \%$ of the Actinostreon are encrusted and even less $(0.9 \%)$ are bored. In reality, these values are probably higher, because many individuals of the large Actinostreon are only preserved as fragments so that not the complete shell could be searched for epi- and endobionts.

Localities HB III to V are characterized by yet another assemblage, in which the large shallow burrower Seebachia (Eoseebachia) sowerbyana is the most prominent faunal element. Only locality HB III provided a statistical sample (Table 3). The Eoseebachia sowerbyana assemblage contains also many elements of the Actinostreon marshii assemblage and in addition to bivalves also serpulids, gastropods, echinoids, sponges, and brachiopods. Nearly all individuals are suspension-feeders $(96.9 \%)$, the rest detritus feeders. In terms of life habits, $65 \%$ of the faunal elements were epifaunal, $32.9 \%$ infaunal, and $2.7 \%$ semi-infaunal. Only $2.1 \%$ of the specimens were bored by acrothoracicans or questionable clinoid sponges, but $14.1 \%$ were encrusted by serpulids and Nanogyra. The small oyster formed clusters and so did Actinostreon marshii. Most of the large Eoseebachia sowerbyana were articulated and none was encrusted or bored suggesting that they never became exhumed. Turnus-bored wood pieces are common at HB IV. In HB III, vertebrate remains occur, probably of ichthyosaur origin. Apart from vertebrae and a rib fragment, they include an articulated flipper (Fig. 5b). The latter suggests that bioturbation by burrowers such as crustaceans no longer played a prominent role in the uppermost part of the Hildoglochiceras Bed. This assemblage probably represents a slightly higher stratigraphic level than the Actinostreon marshii assemblage.

The species diversity between localities varies greatly (Fig. 10): At HB I 25 taxa occur, at HB II 20, but at HB III 49. This variation partly reflects differences in the sample size, which in turn is related to differences in outcrop size and weathering between localities. Apparently, species diversity also changes between different levels of the Hildoglochiceras Bed. HB III, which exhibits the highest diversity, is the stratigraphically highest level sampled and probably represents the greatest degree of faunal condensation judging from the reduced siliciclastic input. Therefore, 

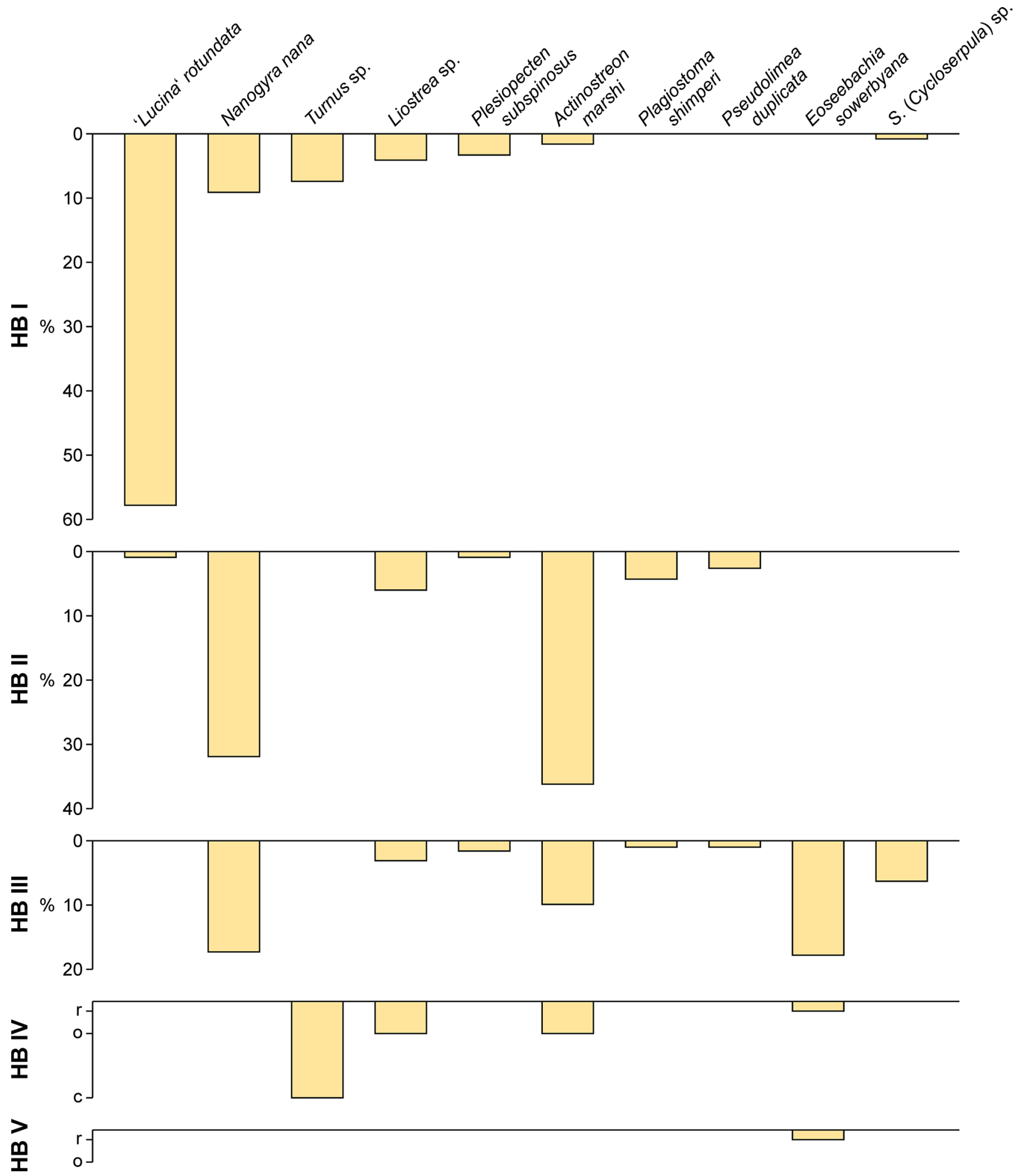

Fig. 9 Distribution (relative abundance) of characteristic taxa in the Hildoglocheras Bed from localities HB I-V. Note that for localities IV and V no statistically significant data are available. Instead, the relative abundance is expressed as rare (r), occurring (o), and com- mon (c). The distinct changes within short distances are due to the fact that fossils weather out from increasingly younger levels from localities HB I to III 
Fig. 10 Sample size, number of taxa, abundance of nektonic/nektonbenthic faunal elements, wood pieces, and of several common benthic macroinvertebrates in the Hildoglochiceras Bed at localities HB I-V. $r$ rare, $o$ occurring, $c$ common

it can be expected to have experienced the highest degree of time-averaging, which would explain the high-diversity value.

\section{The Green Ammonite Beds}

\section{Lithological features}

The Green Ammonite Beds (GAB), also called Umia Ammonite Beds, constitute a well-known marker horizon that can be traced from Katesar in the west to beyond NNE of Lakhapar (Fig. 1), for a distance of more than $10 \mathrm{~km}$, before it is lost at a fault. The GAB are best exposed NNE of the village Lakhapar (Fig. 1c), where it can be traced for several hundred metres, and the following information and discussion mainly refers to this outcrop (localities A-C), with additional information from Mundhan and Katesar (Fig. 11). The lithology and composition of the benthic macrofauna changes only little laterally. Generally, the GAB are characterized by a high iron content and fossil abundance, in particular ammonites but also benthic macroinvertebrates. The horizon is not a single bed, but consists of three brown highly ferruginous muddy sandstone and mudrock units (GAB I, II, and III; Fig. 11), which are separated by silty clay to fine-sandy silt intervals. The latter usually are grey in colour but at the two western localities (Mundhan, Katesar) contain red-brown ferruginous concretions and are partly olive-grey. The ferruginous sandstones are very poorly sorted with a fine-sandy ferruginous mudrock matrix and scattered coarse to very coarse quartz grains that are commonly very well rounded (Fig. 6d). At the Lakhapar locality, GAB II and III lack coarse quartz grains and GAB III is unfossiliferous except for very rare ammonites.

At the Lakhapar localities, GAB I is a very coarse-grained sandstone with scattered quartz granules and a ferruginous mudrock matrix (Fig. 6e). The quartz grains are subrounded to rounded and the amount of matrix varies so that the fabric varies between matrix- and grain-supported. Areas devoid of quartz grains are the remnants of burrows. Some granules are rounded rock fragments (sandstone, metamorphics). Bioclasts are common and concentrated in nests. Most are bivalve fragments with rounded edges. In addition, gastropods, echinoid spines, and foraminifera tests occur. Some shell fragments exhibit microbial/algal borings, and some are strongly bioeroded. They are invariably recrystallized and often heavily ferruginized. Ferruginous ooids, $0.5 \mathrm{~mm}$ in diameter, occur in small clusters, but are generally rare.
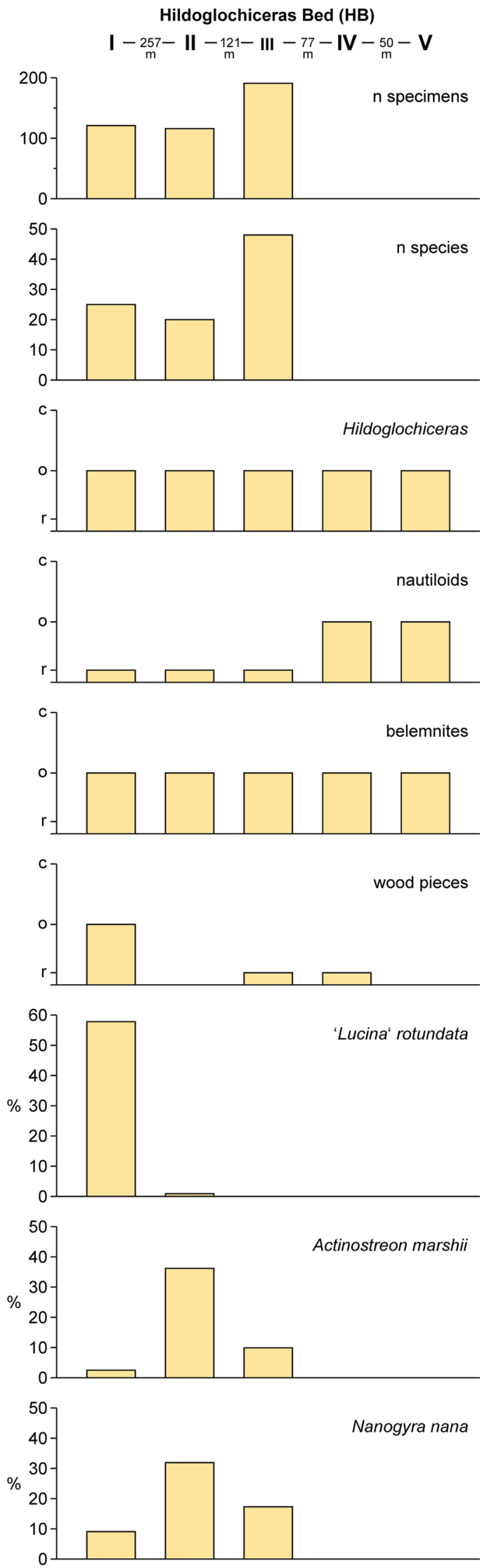
Table 3 Dominant taxa, faunal composition, life habits and feeding modes of the benthic macrofauna of the Hildoglochiceras Bed at localities HB I, II, and III. rel.\%, relative abundance

\begin{tabular}{ll}
\hline HB I & rel.\% \\
121 individuals; 25 taxa &
\end{tabular}

\begin{tabular}{|c|c|}
\hline 'Lucina' rotundata & 57.8 \\
\hline Nanogyra nana & 9.1 \\
\hline Turnus sp. & 7.4 \\
\hline Liostrea A and B & 4.1 \\
\hline Spondylopecten (Plesiopecten) subspinosus & 3.3 \\
\hline Meleagrinella echinata & 2.5 \\
\hline Actinostreon marshii & 2.5 \\
\hline Bivalves & 94.4 \\
\hline Brachiopods & 1.6 \\
\hline Gastropods & 0.8 \\
\hline Echinoderms & 0.8 \\
\hline Serpulids & 0.8 \\
\hline Decapods & 0.8 \\
\hline Calcareous sponges & 0.8 \\
\hline Chemosymbiotic & 57.8 \\
\hline suspension-feeders & 31.5 \\
\hline Detritus/deposit feeders & 2.5 \\
\hline Infauna & 71.1 \\
\hline Epifauna & 28.1 \\
\hline Semi-infauna & 0.8 \\
\hline HB II & rel.\% \\
\hline \multicolumn{2}{|l|}{116 individuals; 20 taxa } \\
\hline Actinostreon marshii & 36.2 \\
\hline Nanogyra nana & 31.9 \\
\hline Liostrea A and B & 6.0 \\
\hline Plagiostoma schimperi & 4.3 \\
\hline Pseudolimea duplicata & 2.6 \\
\hline Serpula (Dorsoserpula) sp. & 2.6 \\
\hline Meleagrinella echinata & 1.7 \\
\hline Bivalves & 94.7 \\
\hline Serpulids & 2.6 \\
\hline Calcareous sponges & 0.9 \\
\hline Decapods & 0.9 \\
\hline Echinoderms & 0.9 \\
\hline Suspension-feeders & 97.4 \\
\hline Detritus/deposit feeders & 1.7 \\
\hline Chemosymbiotic & 0.9 \\
\hline Epifauna & 94.0 \\
\hline Infauna & 4.3 \\
\hline Semi-infauna & 1.7 \\
\hline HB III & rel.\% \\
\hline \multicolumn{2}{|l|}{191 individuals; 48 taxa } \\
\hline Seebachia (Eoseebachia) sowerbyana & 17.8 \\
\hline Nanogyra nana & 17.3 \\
\hline Actinostreon marshii & 9.9 \\
\hline Serpula (Cycloserpula) sp. & 6.3 \\
\hline
\end{tabular}

Table 3 (continued)

\begin{tabular}{ll}
\hline HB III & rel.\% \\
191 individuals; 48 taxa & \\
\hline Serpula (Dorsoserpula) sp. & 3.7 \\
Liostrea sp. A & 3.1 \\
Integricardium bannesianum & 3.1 \\
Megacucullaea eminens & 2.6 \\
Frenguelliella cf. kheraensis & 2.6 \\
Meleagrinella sp. A & 2.6 \\
Opisthotrigonia retrorsa & 2.1 \\
Bivalves & 83.8 \\
Serpulids & 11.0 \\
Gastropods & 2.1 \\
Echinoderms & 2.1 \\
Brachiopods & 0.5 \\
Calcareous sponges & 0.5 \\
Suspension-feeders & 96.9 \\
Detritus/deposit feeders & 3.1 \\
Epifauna & 65.0 \\
Infauna & 32.9 \\
Semi-infauna & 2.7 \\
\hline
\end{tabular}

Large oysters are concentrated in a 10 to 20 -cm-thick shell bed. Wood fragments are rare.

GAB II, in contrast, is a 170 -cm-thick beige to lightbrown Fe-oolitic ferruginous mudrock in two layers (Fig. 11). The nuclei of the elongated, well-sorted berthieroid (berthierine/chamosite; Young 1989) ooids are bioclasts or quartz grains. The fabric is partly matrix-supported, partly grain-supported (Fig. 6h). The irregular distribution of ooids is due to bioturbation. Small ferruginous mudrock granules (1-3 $\mathrm{mm}$ in diameter) occur as do larger intraformational pebbles $(3-5 \mathrm{~cm})$ of the same material. Berthieroid ooids and bioclasts often are partly replaced by iron oxyhydroxide. In the case of ooids, this replacement started from the outside and is very irregular, giving the impression that the ooids are partly corroded or bioeroded (Fig. 6f, g). Bioclasts consist of bivalve fragments heavily bored by microbial organisms, echinoid spines, other echinoderm fragments, and benthic forams. Larger fossils occur scattered. They are common only in the upper of the two layers.

At the Mundhan locality, $6.4 \mathrm{~km}$ further NW, GAB I and II are well exposed (Fig. 11). GAB I is a 50-cm-thick, gravelly, ferruginous mudrock with very poorly sorted quartz grains (Figs. 5c, 6d), which are well rounded (particularly the coarse grains) to subangular (many of the smaller grains). The fabric is mainly mud-supported and exhibits signs of strong bioturbation. In sheltered areas below shells, the matrix is locally developed as a fine-sandy biopackstone with benthic forams, bivalve fragments, and rare Fe-ooids. This suggests that the ferruginous bioclastic 
Table 4 Taxonomic and guild composition of the Green Ammonite Beds I and II

\begin{tabular}{|c|c|c|}
\hline & Trophic group & Mode of life \\
\hline \multicolumn{3}{|l|}{ Plants } \\
\hline \multicolumn{3}{|l|}{ Wood fragments } \\
\hline \multicolumn{3}{|l|}{ Nekton } \\
\hline \multicolumn{3}{|l|}{ Belemnites } \\
\hline \multicolumn{3}{|l|}{ Ammonites } \\
\hline \multicolumn{3}{|l|}{ Macrobenthos } \\
\hline \multicolumn{3}{|l|}{ Serpulids } \\
\hline Serpula (Cycloserpula) intestinalis & $\mathrm{s}$ & ec \\
\hline Serpula (Dorsoserpula) sp. & $\mathrm{s}$ & ec \\
\hline \multicolumn{3}{|l|}{ Gastropods } \\
\hline Onkospira sp. & $\mathrm{h} / \mathrm{d}$ & em \\
\hline Chartronella? sp. & $\mathrm{h} / \mathrm{d}$ & em \\
\hline Neritopsis sp. & $\mathrm{h} / \mathrm{d}$ & em \\
\hline Pseudamaura sp. & $\mathrm{h} / \mathrm{d}$ & $\mathrm{em}$ \\
\hline Obornella sp. & $\mathrm{h} / \mathrm{d}$ & em \\
\hline Leptomaria sp. & $\mathrm{h} / \mathrm{d}$ & em \\
\hline Bathrotomaria cf. dhosaensis & $\mathrm{h} / \mathrm{d}$ & em \\
\hline \multicolumn{3}{|l|}{ Scaphopods } \\
\hline Laevidentalium sp. & $\mathrm{d}$ & $\mathrm{sb}$ \\
\hline \multicolumn{3}{|l|}{ Bivalves } \\
\hline Nuculoma sp. & $d$ & im \\
\hline Grammatodon sp. & $\mathrm{s}$ & $\mathrm{eb}$ \\
\hline Megacucullaea eminens & s & eb \\
\hline Entolium corneolum & $\mathrm{s}$ & er \\
\hline Radulopecten fibrosus & s & $\mathrm{eb}$ \\
\hline Radulopecten moondanensis & s & $\mathrm{eb}$ \\
\hline Radulopecten cf. radians & $\mathrm{s}$ & eb \\
\hline Chlamys (Chlamys) valoniensis & $\mathrm{s}$ & eb \\
\hline $\begin{array}{l}\text { Spondylopecten (Plesiopecten) } \\
\text { subspinosus }\end{array}$ & $\mathrm{s}$ & eb \\
\hline Oxytoma inequivalve & $\mathrm{s}$ & eb \\
\hline Pseudolimea duplicata & s & eb \\
\hline Plagiostoma sp. A & $\mathrm{s}$ & eb \\
\hline Plagiostoma sp. B & s & eb \\
\hline Limatula sp. nov & $\mathrm{s}$ & eb \\
\hline Pseudolimea duplicata & s & eb \\
\hline Ctenostreon proboscideum & $\mathrm{s}$ & eb \\
\hline Gervillella aviculoides & s & si \\
\hline Exogyra tramauensis & s & ec \\
\hline Liostrea cf. blanfordi & $\mathrm{s}$ & ec \\
\hline Liostrea sp. A & s & ec \\
\hline Liostrea sp. C & $\mathrm{s}$ & ec \\
\hline Nanogyra nana & s & ec \\
\hline Gryphaea sicula & $\mathrm{s}$ & ec/er \\
\hline Gryphaea moondanensis & $\mathrm{s}$ & ec/er \\
\hline Liostrea blanfordi & s & ec \\
\hline Placunopsis fuersichi & $\mathrm{s}$ & ec \\
\hline Integricardium bannesianum & s & $\mathrm{sb}$ \\
\hline Seebachia (Eoseebachia) sowerbyana & $\mathrm{s}$ & $\mathrm{sb}$ \\
\hline
\end{tabular}

Table 4 (continued)

\begin{tabular}{|c|c|c|}
\hline & Trophic group & Mode of life \\
\hline Neocrassina $(N$.$) compressa$ & $\mathrm{s}$ & $\mathrm{sb}$ \\
\hline Trigonastarte sp. A & s & $\mathrm{sb}$ \\
\hline Herzogina weissermeli & $\mathrm{s}$ & $\mathrm{sb}$ \\
\hline astartid? sp. A & $\mathrm{s}$ & $\mathrm{sb}$ \\
\hline Anisocardia sp. A & $\mathrm{s}$ & $\mathrm{sb}$ \\
\hline Venilicardia (Venilicyprina) sp. A & $\mathrm{s}$ & $\mathrm{sb}$ \\
\hline Pronoella sp. A & $\mathrm{s}$ & $\mathrm{sb}$ \\
\hline Pronoella n. sp. & $\mathrm{s}$ & $\mathrm{sb}$ \\
\hline Quenstedtia? sp. & $\mathrm{s}$ & \\
\hline Opisthotrigonia retrorsa & $\mathrm{s}$ & $\mathrm{sb}$ \\
\hline Frenguelliella aff. tealei & $\mathrm{s}$ & $\mathrm{sb}$ \\
\hline Frenguelliella cf. kheraensis & $\mathrm{s}$ & $\mathrm{sb}$ \\
\hline Rinetrigonia ventricosa & $\mathrm{s}$ & $\mathrm{sb}$ \\
\hline Pleuromya uniformis & $\mathrm{s}$ & $\mathrm{db}$ \\
\hline anomalodesmatan n.g. n.sp. & $\mathrm{s}$ & $\mathrm{db}$ \\
\hline Pholadomya (P.) aequalis & s & $\mathrm{db}$ \\
\hline \multicolumn{3}{|l|}{ Brachiopods } \\
\hline Acanthorhynchia multistriata & $\mathrm{s}$ & ep \\
\hline Somalithyris lakhaparensis & $\mathrm{s}$ & ep \\
\hline \multicolumn{3}{|l|}{ Echinoderms } \\
\hline 'Pseudodiadema' sp. & $\mathrm{h} / \mathrm{d}$ & em \\
\hline Irregular echinoid & $\mathrm{d}$ & $\mathrm{im}$ \\
\hline phymasomatoid echinoid & $\mathrm{h} / \mathrm{d}$ & em \\
\hline
\end{tabular}

Mode of life: $e b$ epibyssate, $e c$ epifaunal, cemented, er epifaunal, reclining, ep epifaunal, pedicle attached, $w b$ wood-boring, si semiinfaunal, $s b$ shallow-burrowing, $d b$ deep-burrowing, em epifaunal, mobile, im infaunal, mobile. Trophic group: $s$ suspension-feeding, $d$ deposit-feeding, $h / d$ herbivorous/feeding on plant detritus, $s c$ scavenger, $c$ chemosymbiotic

mudrock originally had been a carbonate, which has become impregnated with iron hydroxide. Discernible burrows are $10-12 \mathrm{~mm}$ in diameter and horizontal to oblique. The lower $20 \mathrm{~cm}$ form a concentration of the oyster Gryphaea (Fig. 5d). GAB II, situated $9 \mathrm{~m}$ above, is a 120 -cm-thick, bedded, heavily bioturbated, highly ferruginous Fe-oolitic mudrock with scattered fine quartz grains, scattered shells and bioclasts, among them foraminifers. Shells are partly replaced by iron hydroxide. The ooids are totally recrystallized but some still show remnants of the original laminae. Very commonly, the original ooid mineralogy has been replaced by iron hydroxide. Flat silty micrite pebbles occur near the base. Fossils (ammonites and macrobenthos) are common only in the lowermost bed.

At Katesar, $3.5 \mathrm{~km}$ WNW of Mundhan, the ferruginous succession is slightly coarser-grained (Fig. 11). GAB I a 10-cm-thick ammonite- and oyster-rich bed forming the top of a slightly ferruginous, poorly sorted gravelly sandstone. Likewise, GAB II is a fossil-rich ferruginous siltstone with scattered coarse quartz grains. GAB III is a poorly sorted, 
gravelly bioclastic sandstone. The well-rounded quartz grains partly float in the ferruginous bioclastic mudrock. Apart from large Gryphaea shells, which partly exhibit microbial borings, small bivalve and terebratulid bioclasts are common. Small intraformational ferruginous mudrock clasts occur.

\section{Age}

Due to the abundance of ammonites, the age of the GAB has been well-established (e.g., Bardhan et al. 2007; Krishna et al. 1996; 2011; Pandey et al. 2016). The ammonites represent the denseplicatus, microcanthum and frequens zones of the late Early and the Late Tithonian. The ammonites from Lakhapar discussed by Pandey et al. (2016) had not been collected with sufficient stratigraphic acuity so that the precise ammonite succession could not be established at that locality. Renewed sampling in 2020 showed that GAB I represents the denseplicatus Zone and GAB II the microcanthum Zone, whereas GAB III contains in its lower part Substeueroceras alticostatum Imlay of the uppermost Tithonian frequens Zone (pers. obs.), but also Argentiniceras loncochensis (Steuer) and Spiticeras cf. ducale (Matheron) of the basal Berriasian (Krishna 1991; Krishna et al. 1994).

\section{Benthic macrofauna}

The following account refers to the Lakhapar localities A-C, where the faunal density was high enough for a statistical treatment of the data, but cursory reference is made also to the fossil content at the Mundhan and Katesar localities.

Taphonomic features GAB I and II distinctly differ with respect to their taphonomic attributes. In GAB I shells are loosely to densely packed. The dominant species, the oyster Gryphaea, is only represented by randomly oriented left valves. Of the other specimens about $15 \%$ are articulated, in particular burrowing and endobyssate forms. Their distribution is somewhat patchy and occasionally they form lenticles rather than a bed. The shells are commonly bored by acrothoracican barnacles, but rarely encrusted by Cycloserpula and Nanogyra. In GAB II, the fossil density is lower, patchy and highest in the lower part of the upper layer. 14-37\% of the bivalves are articulated, as are nearly all of the brachiopods. Between 0 and $1.6 \%$ of the shells are bored by acrothoracican barnacles and only $0-0.6 \%$ are encrusted by Dorsoserpula and Nanogyra. The deep-burrowing bivalve Pholadomya is rare but generally occurs in growth position. In both GAB I and II, shell preservation varies between moderately good to very good, and the percentage of fragmentation is higher in GAB I than in GAB II.
Faunal composition The fauna of GAB I is strongly dominated by bivalves (96.8\%), with Gryphaea moondanensis being the dominant species. GAB II (Table 6) is dominated by the rhynchonellid brachiopod Acanthorhynchia multistriata, followed by the terebratulid Somalithyris lakhaparensis. Bivalves (19-35\%) are common, whereas gastropods (0.5-1.6\%), echinoids, serpulids, and scaphopods are rare (Fig. 12).

Benthic assemblages The benthic assemblages of GAB I and II at Lakhapar differ distinctly both in species diversity and composition, whereby all taxa of GAB I also occur in GAB II, but with different relative abundances (Fig. 12).

GAB I is characterized by the Gryphaea moondanensis assemblage (Table 5). The name-giving taxon (Fig. 13b), an oyster resting freely on the substrate after a cemented early juvenile stage, accounts for $62 \%$ of all individuals, followed by the shallow-burrowing Opisthotrigonia retrorsa (Fig. 13d) and Herzogina weissermeli (Fig. 13c) and the semi-infaunal Gervillia aviculoides (Fig. 13g). Apart from bivalves, the only other benthic faunal group is serpulids (3.2\%). All faunal elements were suspensionfeeding, and nearly three-fourth of them lived as free recliners, or as cemented or byssate forms on the substrate. Gryphaea occurs in patches and small lenticles, and is invariably disarticulated, whereby right valves are extremely rare. Wood fragments are rare, and ammonites occur scattered. Only $3.2 \%$ of the specimens are encrusted by Nanogyra or Cycloserpula, but none are bored.

The same assemblage occurs further west, at Mundhan, where left valves of Gryphaea moondanensis are commonly bored by acrothoracican barnacles and rarely encrusted with Liostrea. The lenticular oyster concentrations occur at two levels, separated by $40 \mathrm{~cm}$. Gryphaea shells are all disarticulated and randomly oriented (convex-up: convex-down: oblique valves $=43: 50: 28$ ). At Katesar, still further west, the assemblage exhibits very similar features, but apart from common acrothoracicans, also questionable sponge (Entobia?) and phoronid borings (Talpina isp.) occur. Rare additional faunal elements are the terebratulid Somalithyris lakhaparensis and the bivalves Pholadomya (P.) sp., and Gervillella aviculoides.

In GAB II, the density of fossils is also somewhat patchy, but fairly uniform between the three sampling sites (Figs. 14, 15). In particular, the rhynchonellid Acanthorhynchia multistriata (Fig. 13i) occurs in small nests. It is the most dominant element of the Acanthorhynchia multistriata-Somalithyris lakhaparensis assemblage (Table 6), which is quite diverse (19-27 taxa) and contains taxa of a wide size range. Conspicuous are the huge epibyssate pectinid Radulopecten moondanensis, which reaches nearly $20 \mathrm{~cm}$ in height (Fig. 13e), large semi-infaunal 


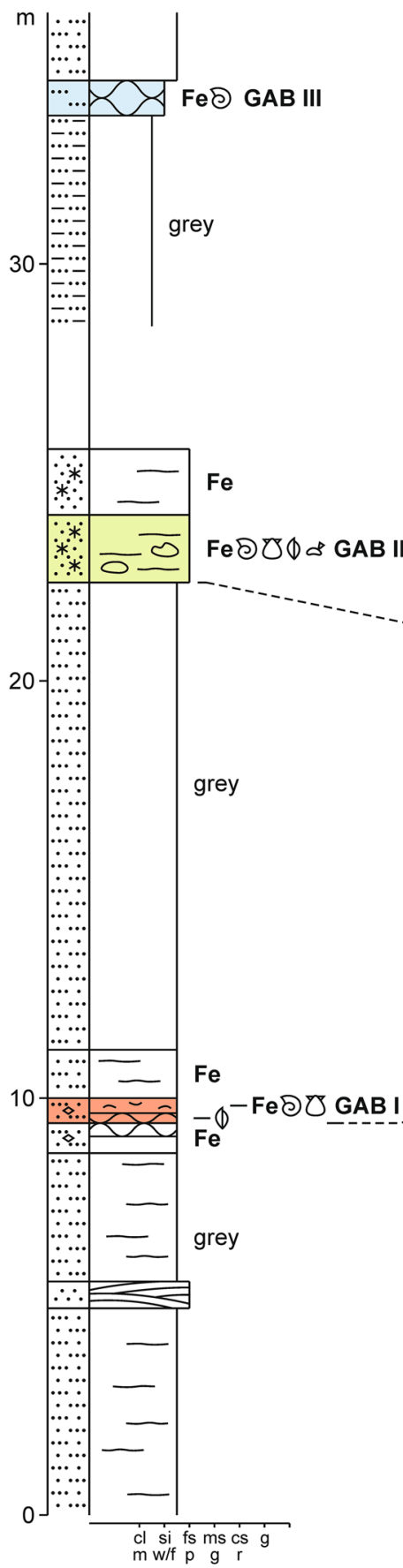

Lakhapar

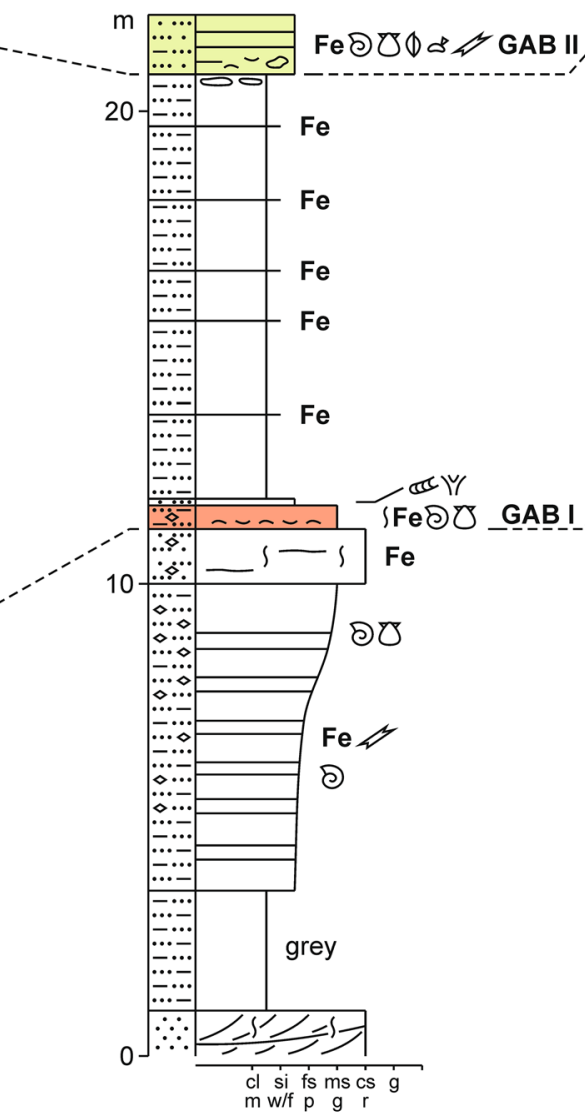

Mundhan $\mathrm{m}|\cdots \cdot \cdot|$

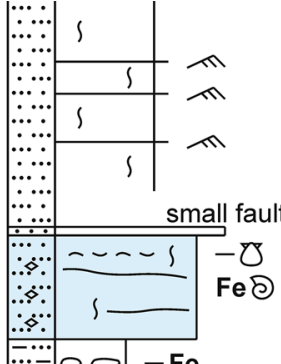

30

$\begin{array}{lll}\cdots \cdots \\ \cdots \cdots & 00 & -\mathrm{Fe}\end{array}$

GAB III

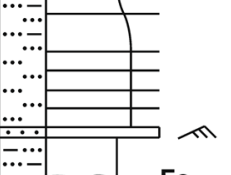

\begin{tabular}{c|c|c}
$\cdots \cdot \cdots \cdot . \cdot$ & 0 & $-F e$
\end{tabular}

:.:.:.

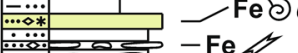

… OD Fel

然果

GAB II

$\cdots * ट 0$

$* \therefore 00$

$\because \cdots * *$

$* . .000 \mathrm{Fes}$

Fes Dy
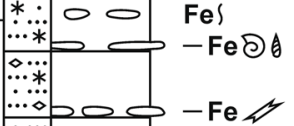

$-\mathrm{Fe} /$

*.* $\mathrm{bec}-\mathrm{Fe}$

*... S

-FeD PO GAB I

$\therefore-1-1$

$\longrightarrow \mathrm{Fe}$

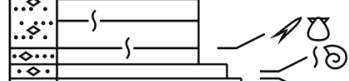

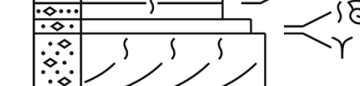

$0-$

$\because$

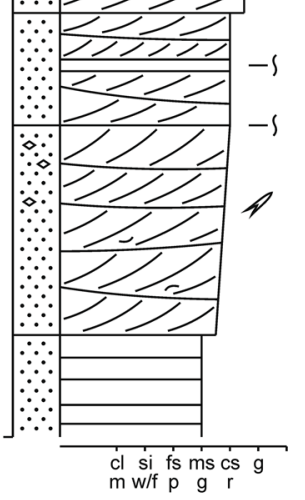

Katesar

$*$ glauconite
interlayered bedding
trough cross-bedding
hummocky cross-bedding
$\square$ nodular

-- shells

0 bivalves

$\exists$ gastropods

(D) ammonites

4 belemnites

(1) brachiopods

\section{GAB III}

GAB I

d echinoids

$\$$ wood fragments

5 bioturbation

Rhizocorallium

$\curlyvee$ small Thalassinoides

IV large Thalassinoides 
Fig. 12 Comparison of faunal composition and species diversity between Green Ammonite Beds I and II north of Lakhapar village. Shown are only the most abundant species

Gervillella aviculoides (Fig. 13g), the epibyssate Megacucullaea eminens (Fig. 13a) and the shallow-infaunal Seebachia (Eoseebachia) sowerbyana (Fig. 13f). At the other end of the size range are tiny echinoids and a number of small to tiny gastropods (e.g., Onkospira, Neritopsis) and bivalves (e.g., Limatula, Plesiopecten). Of particular interest are two trigoniid species, Opisthotrigonia retrorsa (Fig. 13d) and Rinetrigonia ventricosa, which herald the great morphological radiation of the group in the early Cretaceous of the area (Kitchin 1903). Nearly all taxa are suspension-feeders (97-99\%) and 76 to $89 \%$ belong to the epifauna (Fig. 15). Between 14 and $37 \%$ of the bivalves are articulated (among them many Gervillella and most infaunal taxa) as are nearly all brachiopods. Rarely, the deepburrowing Pholadomya is preserved in growth position.

At Mundhan, the density of benthic fossils is lower, but the rhynchonellid Acanthorhynchia multistriata, the bivalves Radulopecten moondanensis, Atreta, Liostrea, Gervillella, Megacucullaea eminens, the gastropod Leptomaria, and serpulids point to the same assemblage as at Lakhapar. At the Katesar locality, $3.5 \mathrm{~km}$ further west, the low-density fossil assemblage more closely resembles the Gryphaea moondanensis assemblage of GAB I.

\section{Discussion}

\section{Palaeoenvironmental interpretation}

\section{Hildoglochiceras Bed}

Belemnites, nautiloids, and ammonites indicate that the Hildoglochiceras Bed is a fully marine unit, which has been deposited offshore below the fair-weather wave-base and probably also below the storm wave-base. It may have been influenced occasionally by storm-induced currents, but any primary evidence such as sedimentary structures has been subsequently obliterated by bioturbation. Within the bed, there is a change from the infaunal "Lucina" rotundata assemblage to the epifaunal Actinostreon marshii assemblage and finally to the mixed epifaunal-infaunal

$\varangle$ Fig. 11 Detailed sections through the Green Ammonite Beds (GAB I to III). a Section north of Lakhapar village, southern rim of Jara Dome. b Mundhan section, Mundhan anticline, north of Mundhan village. c Section east of Katesar temple. For locality details see Fig. 1 and Table 1. $c l$ clay, si silt, $f s$ fine-sand, $m s$ medium-sand, $c s$ coarse-sand, $g$ gravel, $m$ mudstone, $w / f$ wackestone/floatstone, $p$ packstone, $g$ grainstone, $r$ rudstone

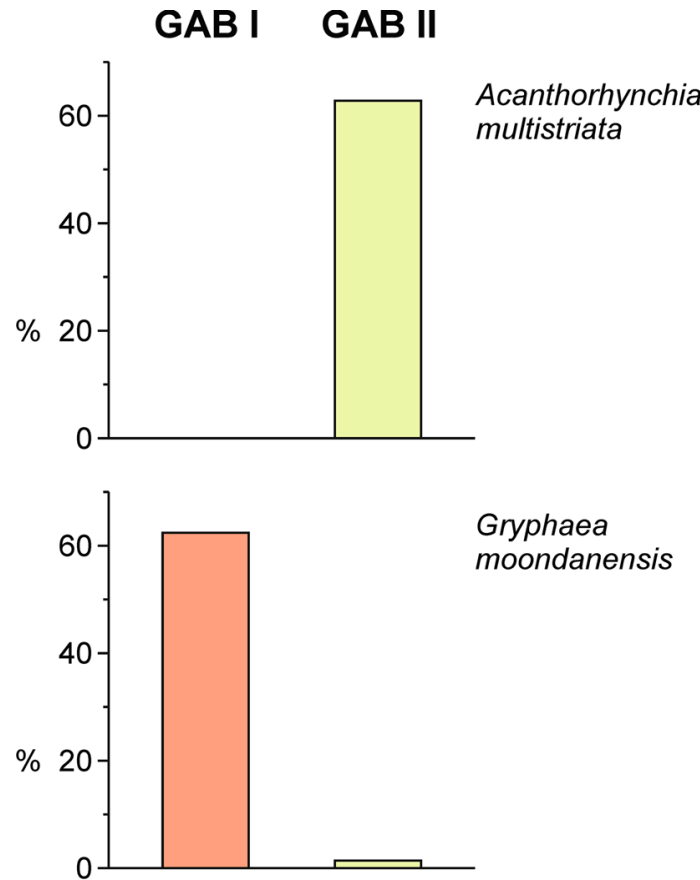

$\% 20$

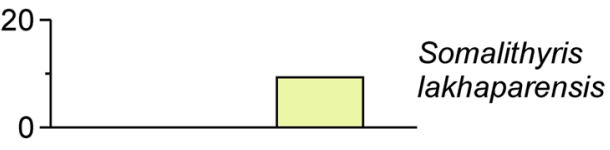

$\% 20$

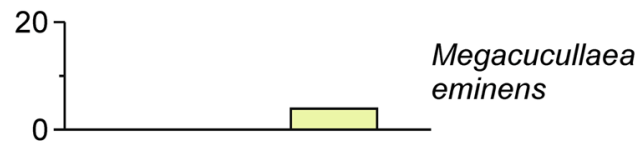

$\% 20$
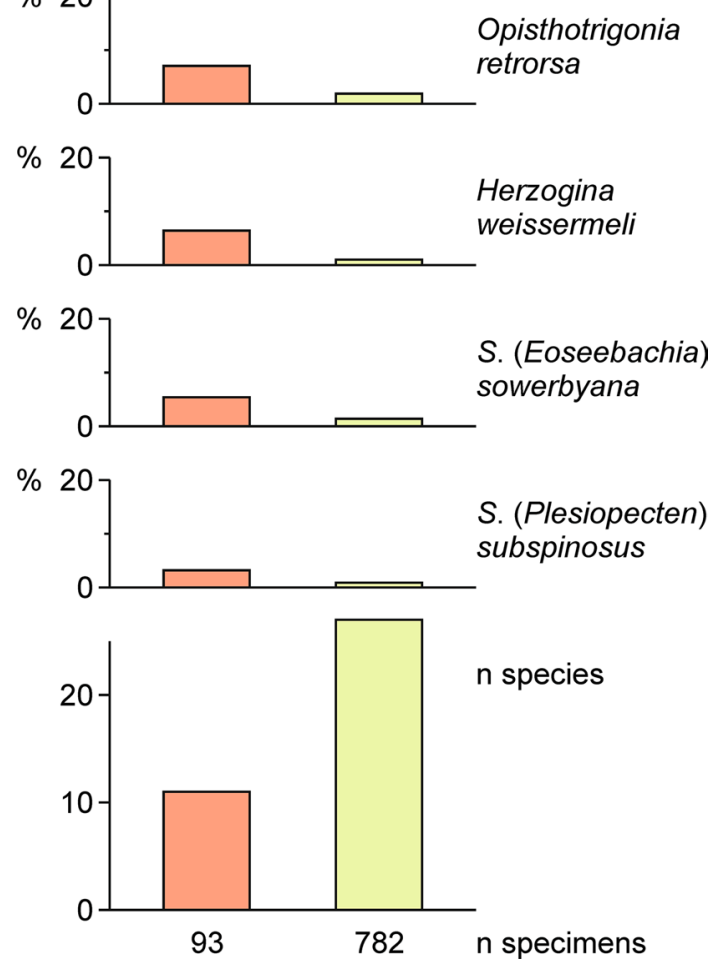
Table 5 Taxa, faunal composition, life habits and feeding modes of the benthic macrofauna of the Green Ammonite Bed I at locality B. rel.\%, relative abundance

\begin{tabular}{ll}
\hline 93 individuals; 11 taxa & rel.\% \\
\hline Gryphaea moondanensis & 62.4 \\
Opisthotrigonia retrorsa & 7.5 \\
Gervillella aviculoides & 6.4 \\
Herzogina weissermeli & 6.4 \\
Seebachia (Eoseebachia) sowerbyana & 5.4 \\
Spondylopecten (Plesiopecten) subspinosus & 3.2 \\
Serpula (Cycloserpula) sp. & 3.2 \\
Nanogyra nana & 2.1 \\
Bivalves & 96.8 \\
Serpulids & 3.2 \\
Suspension-feeders & 100 \\
Epifauna & 73.2 \\
Infauna & 20.4 \\
Semi-infauna & 6.4 \\
\hline
\end{tabular}

Eoseebachia sowerbyana assemblage. The find of an articulated flipper in the upper part of the bed at HB III (Fig. 5b) indicates that the substrate was soft enough for the flipper to sink into the sediment and thus escape scavenging. Puzzling is the low percentage of bored and encrusted shells. Condensation usually implies a long residence time of shells on the sea floor, i.e., time enough for their severe biogenic alteration. Some shells indeed show signs of microbial bioerosion, but the majority is well-preserved. A possible explanation is that after death of the organisms the biogenic hard parts became soon covered with a thin film of sediment, which protected them from attacks by boring or encrusting biota.

The heavily bioturbated sandy bioclastic wackestone immediately below the ferruginous crust that forms the base of the Hildoglochiceras Bed at locality HBI is thought to have formed in a protected environment, overlying coarsegrained sandstones which are interpreted as nearshore bars. They contain scattered bivalves and other fossils such as locally abundant juvenile ammonites.

\section{Green Ammonite Beds}

The taphonomic features of GAB I point to currents or waves as the concentration agents. This is supported by the abundant very coarse quartz grains, but is contradicted by the ferruginous mudrock matrix in which the coarse particles float. The depositional environment of GAB I is thought to have been close to the storm wave-base. Rare high-energy events reworked and concentrated the shells and quartz grains. During long, quiet intervals between such events ferruginous mud accumulated, and intense bioturbation (corresponding
Fig. 13 Characteristic bivalves and brachiopods occurring in the Green Ammonite Beds. a Megacucullaea eminens Cox, 1940. b Gryphaea moondanensis Cox, 1952. c Neocrassina (N.) compressa (J. de C. Sowerby, 1840). d Rhinetrigonia retrorsa (Kitchin, 1903). e Radulopecten moondanensis Cox, 1940. f Seebachia (Eoseebachia) sowerbyana (Holdhaus, 1913). g Gervillella aviculoides (J. Sowerby, 1814). h Somalithyris lakhaparensis Mukherjee and Shome, 2017. i Acanthorhynchia multistriata (Kitchin, 1900)

to a bioturbation index of 5-6; Taylor and Goldring 1993) produced the preserved sedimentary fabric.

The taphonomic features of GAB II differ in their complete lack of sorting of skeletal elements, considerable percentage of articulated valves, rare burrowing individuals preserved in growth position, and small nests of brachiopods. These features indicate a generally quieter environment, although disarticulated infaunal bivalves point to occasional reworking. An offshore position below the storm wave-base, but within the reach of occasional storm-induced currents is envisaged, which caused winnowing and minor reworking. The distinctly higher species diversity compared to GAB I probably reflects mainly a higher degree of condensation and thus a longer time span for the accumulation of GAB II. The predominantly quiet conditions provided ample time for the sediment to become thoroughly bioturbated. The extreme scarcity of shelly infaunal deposit feeders such as nuculids may be due to the iron content of the sediment. The berthieroid ooids are thought to be autochthonous, having grown under mildly reducing conditions within the sediment (e.g., Young 1989; Clement et al. 2020) and redistributed by burrowers. They indicate sediment starvation (e.g., Burkhalter 1995; Collin et al. 2005; Föllmi 2016). The iron source might have been lateritic soils, but could also be a swampy delta plain, reworked during transgression. The percentage of bored or encrusted shells in GAB I and II, and this also applies to the common shells of ammonoids, is even lower than in the Hildoglochiceras Bed but the explanation of this phenomenon offered here (i.e., a short residence time on the sea floor) is the same. The common shell debris may be partly of biogenic origin and thus does not necessarily point to an elevated turbulence level. It appears that the difference in the environmental position between GAB I and II is that the latter accumulated in a deeper, more offshore position during a longer period of time. The distinctly lower shell density indicates that the sea floor was only sparsely colonized at any time by shell-bearing macroinvertebrates. For the nearly unfossiliferous GAB III an even deeper position is assumed, based on the fine-grained sediment and total bioturbation (Fig. 16).

\section{Sequence stratigraphic and palaeoclimatic aspects}

The Jhuran Formation of the western Jara Dome shows a distinct cyclic architecture (Fürsich and Pandey 2003, 


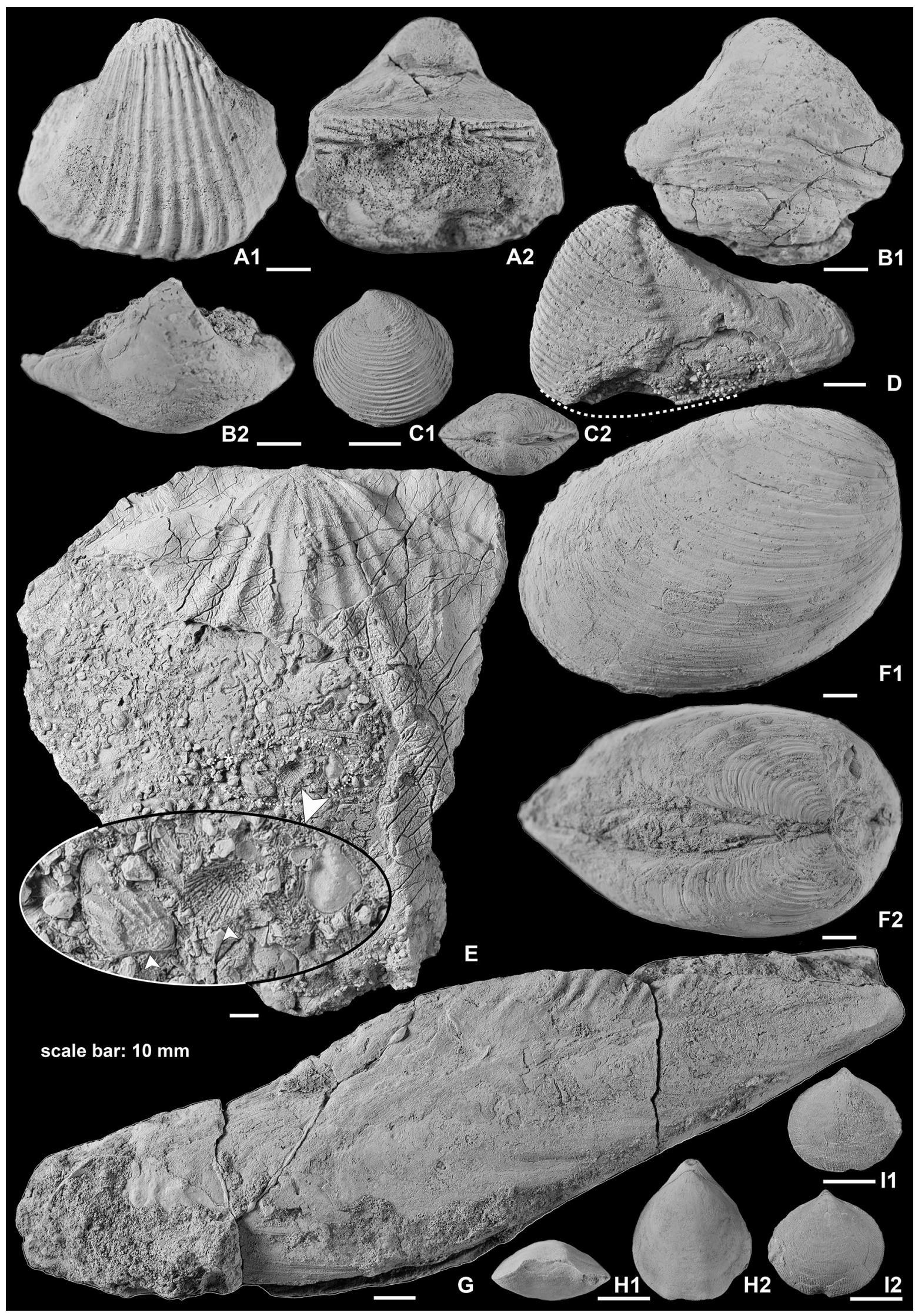


fig. 3; Desai and Biswas 2018, fig. 15). These cycles are generally highly asymmetric, and typically several metres to decametres in scale. Such cycles are common in shallow shelf settings of the geological record (parasequences; e.g., Van Wagoner et al. 1988; Arnott 1995; Fürsich et al. 2005; Sharafi et al. 2013). The transgressive systems tract (TST) up to the maximum flooding zone (MFZ) is usually thin and often just represented by the reworked top of the preceding highstand systems tract (HST). Such thin TST deposits characteristically consist of bioturbated, very poorly sorted sandstones with scattered very coarse to gravel-sized quartz grains and a ferruginous or calcareous matrix. Fossils occur (large, thick-shelled bivalves, scattered coral heads) but are never common except in the Hildoglochiceras Bed, the Green Ammonite Beds, and in the unit just below the Green Ammonite Beds, whereas HST deposits are nearly always unfossiliferous. Bioturbation is thought to be responsible for the poor sorting and led to mixing of top HST, TST, and MFZ deposits, the former being coarse-grained and the latter fine-grained (commonly mudrocks). The cycles are most likely related to a deltaic system, the so-called Jhuran Delta (Desai and Biswas 2018), which prograded into the basin from east to west. Progradation of delta lobes during regression was interrupted by phases of delta destruction during transgression. Not all metre-thick sandstone units of the Jhuran Formation are regarded by us as of delta-front or distributary mouth-bar origin as assumed by Desai and Biswas (2018). Rather, sand of deltaic origin was also spread by currents across the basin forming sand sheets. The T-R cycles in the Tithonian part of the Jhuran Formation (Fig. 17) record relative changes in sea level. To which extent the high-frequency cycles are eustatic cannot be determined with certainty, as their biostratigraphic control is too poor. If eustatic, they possibly correspond to fourth- or fifth order cycles. The three condensed beds of the GAB would then be the MFZ of such cycles. Together, however, they represent the MFZ of a higher rank of cyclicity (?3rd order). The late HST of that cycle would be the coarse-grained shelly sandstones of the Trigonia Sandstone member (Fig. 17), which are topped by the transgressive shell lag (top Trigonia Bed) of the next T-R cycle. The Hildoglochiceras Bed would possibly represent the late TST and MFZ of another 3rd-order cycle. It is, however, likely that also climatic factors such as phases of increasing aridity, which would lead to a reduction of terrigenous sediment input, and autocyclic processes, such as switching of delta lobes, exerted some influence on the cycle pattern.

The MFZ of the Hildoglochiceras Bed and the Green Ammonite Beds exhibit some similarities, but also pronounced differences: Both are bioturbated, poorly sorted, record sediment starvation, and contain a diverse benthic macrofauna as well as abundant ammonites, but while the HB is characterized by lime mud, the GAB stand out by their high iron content, originally most of it berthierine but changed to iron oxyhydroxide during weathering. They, therefore, correspond to typical condensed horizons, whereby the degree of condensation never reached the stage, where index fossils became mixed. In the HB, input of siliciclastic sediment from a terrigenous source ceased drastically, the scattered coarse quartz grains being reworked from the underlying HST deposit or stem from occasional redistribution of HST sediments within the basin during TST. In the case of the GAB, fine-grained sediment (clay, silt) reached the basin, but the net sedimentation rate was so low that dissolved iron accumulated on the sea floor to form autogenic glauconite or berthierine grains (GAB I) and berthierine iron ooids (GAB II) just below the sediment water interface.

The lower boundary of the Hildoglochiceras Bed records a brief phase of subaerial exposure and most likely forms the top of a higher frequency T-R cycle within the transgressive systems tract shown in Fig. 4. At the locality HB I, it is documented by dissolution of carbonate resulting in a small-scale karst topography and by the formation of a ferruginous crust (comparable to one documented by Wilmsen et al. 2014). This interpretation is supported by the irregular cement-filled cavities immediately below the boundary and is also corroborated by the 2-m-thick layer of decalcified sandstone underlying the unit at the locality HB II.

The different lithologies of the two condensed units suggest different climatic conditions during their formation. The intercalation of a thin carbonate unit within the approximately 700-m-thick, otherwise exclusively siliciclastic Kimmeridgian-Tithonian succession of the Jara Dome points to a relatively arid phase, during which terrestrial sediment input into the basin was strongly reduced and no longer diluted the biogenic carbonate production. An alternative interpretation that the carbonate unit is the result of switching of delta lobes, exposed for example in the Jara Mara River $5.5 \mathrm{~km}$ to the southeast (Desai and Biswas 2018), and is, therefore, autocyclic is regarded as less likely. In contrast, the highly ferruginous nature of the GAB indicates more humid conditions, the iron having been introduced by rivers or derived from delta-plain swamps and lateritic soils, which were reworked during transgression. As Desai and Biswas (2018) demonstrated, much of the sediments of the Jhuran Formation were related to large delta systems.

\section{Comparison between the maximum flooding zones}

The HB localities share with GAB II a relatively high species diversity, a distinct concentration of fossils with respect to underlying and overlying strata, the scarcity of bored and encrusted shells, a thoroughly bioturbated sediment, and a lack of sorting both with respect to biogenic and abiogenic sediment components. They share with GAB I the presence of scattered coarse quartz grains. All three horizons share 
Fig. 14 Characteristic faunal elements of the Green Ammonite Bed II north of Lakahapar and their lateral variation in relative abundance between three sampling points $(\mathrm{A}-\mathrm{C})$. The changes in the relative abundance of the brachiopods are due to clustering

that nektonic and nekto-benthic faunal elements (ammonites, belemnites) are common, that wood fragments occur, and boring and encrusting biota are surprisingly rare. The various assemblages are all strongly dominated by suspensionfeeders, except at HB I, where a chemosymbiotic bivalve prevails, and in most of them epifaunal guilds (cemented, byssate or reclining) dominate. HB and GAB differ in sediment composition (calcareous versus ferruginous), in their ammonite diversity (low in the case of $\mathrm{HB}$ ), and most clearly in the composition of the benthic macrofauna. Gryphaea is not present in the HB, whereas lucinids and Actinostreon marshii have not been recorded from the GAB. Several other taxa are shared, although occurring in different abundances. Examples are characteristic taxa such as Megacucullaea eminens, Opisthotrigonia retrorsa, and Eoseebachia sowerbyana. These differences reflect differences in ecological parameters. As outlined above, sediment characteristics point to different climatic regimes between the $\mathrm{HB}$ and $\mathrm{GAB}$ horizons. The resulting differences in sediment input, substrate conditions, nutrient input and pore-water chemistry surely also influenced the species composition.

\section{Can we recognize sedimentary condensation associated with maximum flooding zones based on ecological and taphonomic features?}

Several sedimentological features indicate sediment starvation and sedimentary condensation, but often not a single feature is diagnostic but only their combination. The relevant sediments are commonly very poorly sorted and the thin units are internally often complex. A useful criterion may be a thin carbonate unit within an overall siliciclastic succession. Among the best indicators are authigenic minerals such as glauconite, the verdine group, berthierine iron ooids, phosphorites, and hardgrounds (Föllmi 2016).

With respect to biogenic components, evidence is less forthcoming. One indicator is the fossil density. Sediment starvation increases the relative abundance of biogenic hard parts and may lead to condensed autochthonous shell concentrations. The problem is that shell concentrations are very common in the geological record and are, in most cases, caused by physical processes such as waves or currents or by intrinsic factors such as high fecundity and gregarious behaviour of organisms (e.g., Kidwell et al. 1986). The time scale involved ranges from hours (e.g., in the case of storms) to decades or at the most a few hundred years and thus does not fulfil the criteria of a condensed horizon, which refers to larger time scales (Föllmi 2016). Taphonomic features are
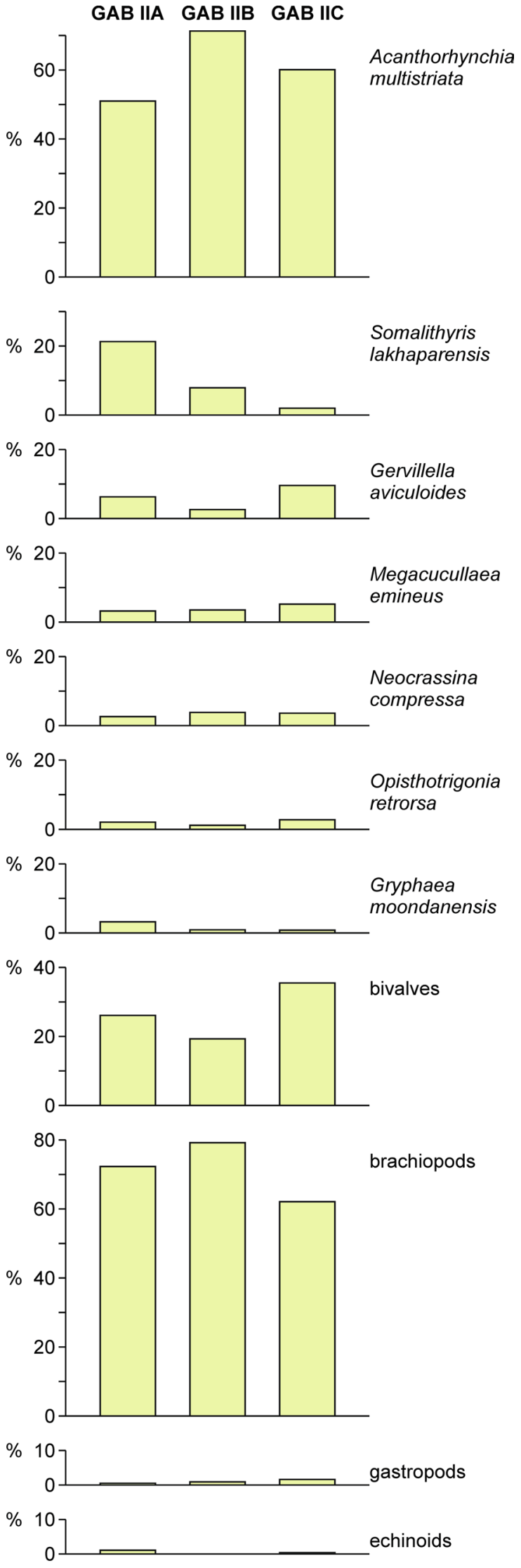

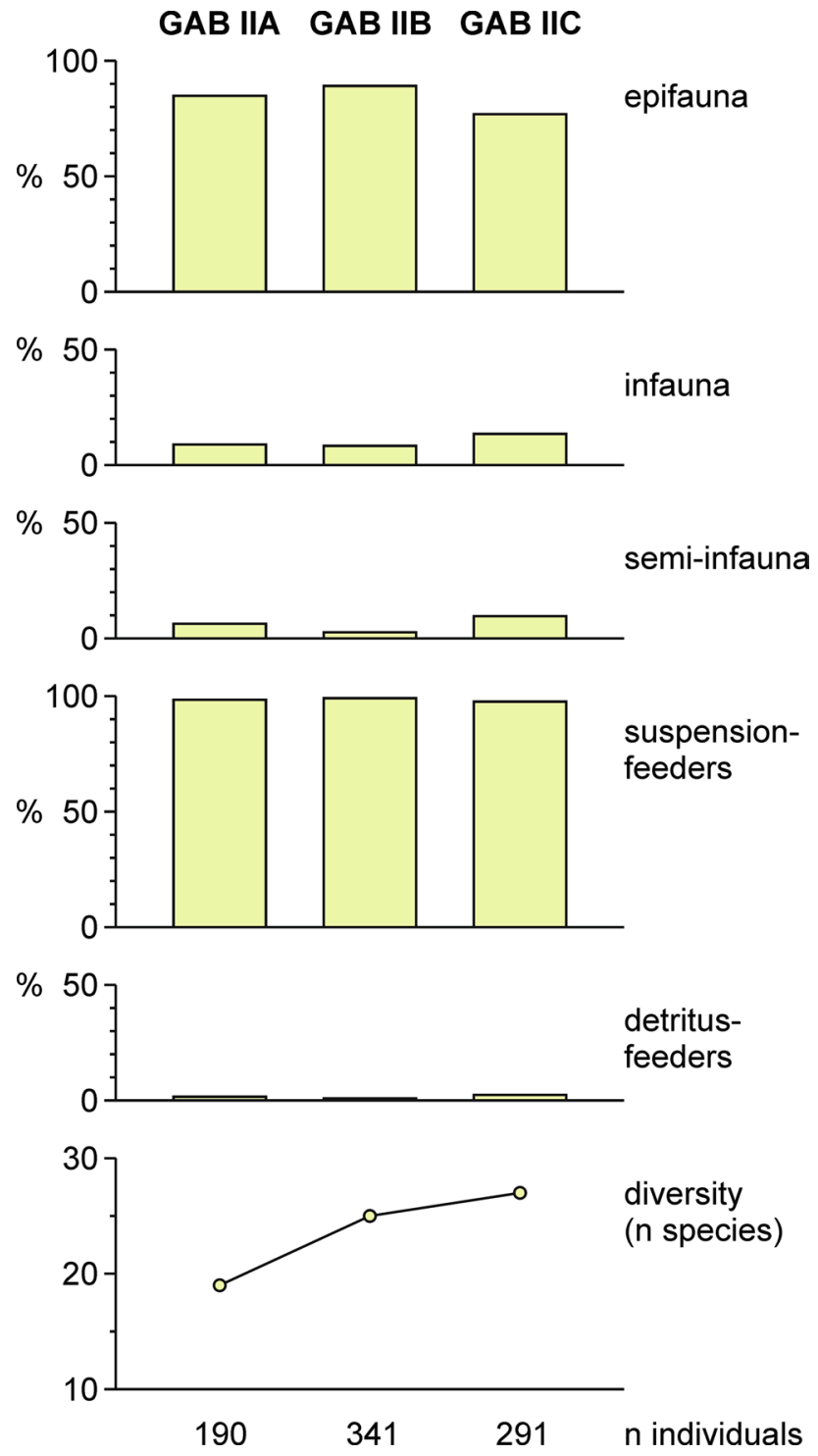

Fig. 15 Ecological features (mode of life, trophic guilds and species diversity of the three statistical samples of GAB II north of Lakhapar village

more promising. Sediment starvation due to low sediment input or bypassing commonly increases the residence time of shells on the sea floor, which then serve as substrate for an encrusting and endolithic biota. The weakness of this criterion is again the time span. Several generations of endoand epilithic organisms may totally encrust and/or heavily damage shells within several decades. Moreover, as the present examples show, the converse, i.e., a low percentage of encrusted and bored shells, is no firm proof against condensation. Another criterion is the species diversity. In condensed beds the species diversity of autochthonous assemblages appears to be generally high, due to the telescoping of several communities, which colonized the sea floor during minor environmental fluctuations, into a single bed. However, when such a high diversity has been produced by mixing of faunas from different environments (allochthonous time-averaging of Fürsich and Aberhan 1990) no conclusion about an unusually long time span for the formation of the assemblage can be drawn. Condensed beds at maximum flooding zones are generally situated offshore, commonly below the storm wave-base and accumulate under predominantly quiet conditions. As a result, bivalves are commonly articulated (e.g., Archuby 1990; Fürsich and Pandey 2003) and occasionally preserved in growth position. This kind of preservation is, of course, also found when a benthic community suffers sudden death by obrution, but the associated taphonomic features should easily help to differentiate between the two situations.

For the in-situ mixing of faunas and sediments bioturbation plays an important role. Condensed beds are invariably bioturbated (except when accumulating in anoxic environments), and primary sedimentary structures are never preserved. This is nicely documented in the examined examples, which document the mixing of late HST sediments and faunas with those of the TST and MFZ (at locality HB I).

A particularly critical factor is the dissolution of biogenic hard parts of condensed beds, which depends on the water depth, the chemical environments, physical reworking, the residence time of biogenic hard parts within the taphonomic active zone, and the shell mineralogy (e.g., Aller 1982; Davies et al. 1989). For example, Cummins et al. (1986) demonstrated the rapid dissolution of shells on the floor of the Gulf of Mexico. This process may lead to horizons poor in shell content, the condensed nature of which may not be recognized. The Green Ammonite Bed III at Lakhapar might be such an example. It is a 80-cm-thick, nodular, highly ferruginous siltstone, in which fossils are extremely rare. It is, however, strongly condensed, because at its base Substeueroceras alticostatum of the uppermost Tithonian Frequens Zone has been found (pers. obs.), whereas Krishna (1991) and Krishna et al. (1994) recorded basal Berriasian ammonites from the same unit. The scarcity of ammonites and the complete lack of benthic macroinvertebrates in this clearly condensed bed appear to have been due to dissolution of biogenic hard parts. The only other, less likely explanation would be that the sea-floor conditions were unfavourable for benthic organisms.

In conclusion, the only decisive biological feature diagnostic of condensation is the mixing of autochthonous index fossils from different zones/subzones. For less severe cases of condensation, the combination of several biological features such as a relatively high shell density and species diversity, ecological incompatibility of autochthonous 
Table 6 Dominant taxa, faunal composition, life habits and feeding modes of the benthic macrofauna of the Green Ammonite Bed II at localities A, B, and C. rel.\%, relative abundance

\begin{tabular}{ll}
\hline GAB IIA & rel.\% \\
190 individuals; 19 taxa & \\
\hline
\end{tabular}

Acanthorhynchia multistriata
Somalithyris lakhaparensis
Gervillella aviculoides
Gryphaea moondanensis
Megacucullaea eminens
Neocrassina compressa
Opisthotrigonia retrorsa
Seebachia (Eoseebachia) sowerbyana
Spondylopecten (Plesiopecten) subspinosus
Brachiopods
Bivalves
Echinoids
Gastropods
Suspension-feeders
Detritus feeders
Epifauna
Infauna
Semi-infauna

\begin{tabular}{ll} 
Semi-infauna & 6.3 \\
\hline GAB IIB & rel. $\%$
\end{tabular}

341 individuals; 25 taxa

Acanthorhynchia multistriata

Somalithyris lakhaparensis

Neocrassina compressa

Megacucullaea eminens

Gervillella aviculoides

Opisthotrigonia retrorsa

Pholadomya (P.) aequalis

Seebachia (Eoseebachia) sowerbyana

Spondylopecten (Plesiopecten) subspinosus

Brachiopods

Bivalves

Gastropods

Serpulids

Suspension-feeders

Detritus feeders

Epifauna

Infauna

Semi-infauna

GAB IIC

251 individuals; 27 taxa

Acanthorhynchia multistriata

Gervillella aviculoides

Megacucullaea eminens

Neocrassina compressa

Opisthotrigonia retrorsa
Table 6 (continued)

\section{GAB IIC}

rel.\%

251 individuals; 27 taxa

Neocrassina weissermeli

Somalithyris lakhaparensis

Entolium (E.) corneolum

Seebachia (Eoseebachia) sowerbyana

Radulopecten moondanensis

Brachiopods

Bivalves

Gastropods

Echinoids

Scaphopods

Suspension-feeders

Detritus feeders

Epifauna

Infauna

Semi-infauna

faunal elements (e.g., Fürsich and Kauffman 1984), a high degree of shell alteration by endo- and epilithic organisms, and intensive bioturbation provides good evidence for sedimentary condensation, especially when used together with sedimentological criteria.

\section{Conclusions}

(1) The Tithonian part of the Jhuran Formation of the western Jara Dome is characterized by strongly asymmetric coarsening- and shallowing-upward transgressiveregressive cycles. In the approximately 400-m-thick siliciclastic succession fossils are rare and generally consist of very sporadic ammonites. The scarcity of fossils is partly due to relatively high sedimentation rates. Scattered large bivalves and corals are confined to the transgressively reworked tops of the coarseningupward cycles.

(2) Two notable exceptions to this pattern exist: The Lower Tithonian Hildoglochiceras Bed and the upper Lower to Upper Tithonian Green Ammonite Beds contain abundant ammonites and a rich and diverse benthic macrofauna dominated by bivalves or brachiopods. They are interpreted as representing MFZ deposits accumulating during times of sediment starvation.

(3) The 1.5-m-thick Hildoglochiceras Bed and its underlying fossiliferous mixed carbonate-siliciclastic bed are the only carbonate units in the succession, sandwiched between an underlying coarse-grained sandstone package and a thick overlying dark-grey argillaceous 


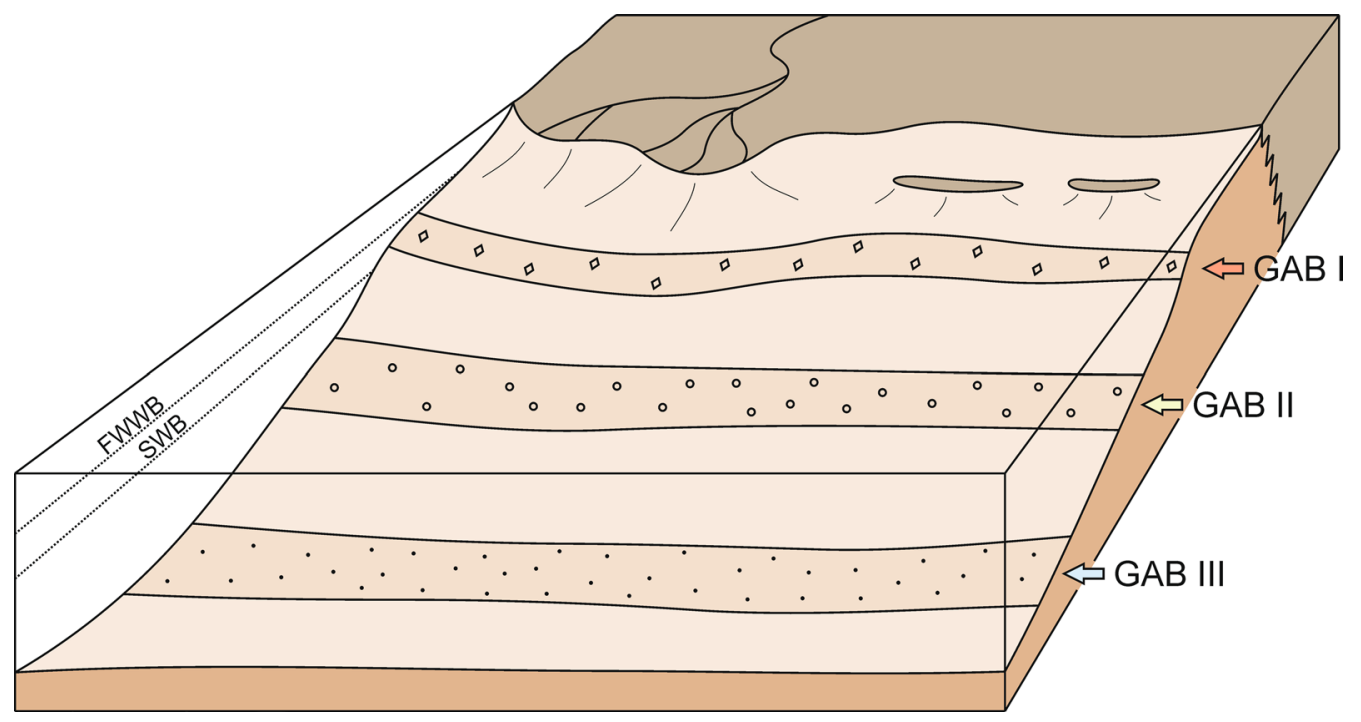

Fig. 16 Model showing the assumed positions of the three Green Ammonite Beds along an onshore-offshore transect

silt unit. The silty bioclastic marl contains, particularly in its lower part, abundant coarse quartz grains reworked by burrowing crustaceans from the underlying TST deposits. The bed contains a succession of three autochthonous benthic assemblages in addition to belemnites, ammonites, and nautiloids. The lower assemblage is dominated by the presumably chemosymbiotic bivalve "Lucina" rotundata, the middle one by epifaunal suspension-feeding bivalves (the oysters Actinostreon marshii, Nanogyra nana, and Liostrea sp.), and the upper one by the large shallow-burrowing suspension-feeding bivalve Seebachia (Eoseebachia) sowerbyana. The latter assemblage exhibits the highest diversity and is thought to document maximum condensation.

(4) The three Green Ammonite Beds differ distinctly in sediment character and faunal composition. GAB I is a very coarse-grained sandstone with a ferruginous mudrock matrix. Apart from ammonites it contains a low-diversity bivalve assemblage dominated by the reclining oyster Gryphaea moondanensis, which forms thin lenticular shell beds and shows clear signs of reworking, most likely under the influence of storm waves. The high iron content indicates sediment starvation in an environment above the storm wave-base. GAB II is a ferruginous Fe-oolitic mudrock with a moderately abundant high-diversity fauna composed of ammonites, bivalves, brachiopods, gastropods, and echinoids. The autochthonous assemblage is dominated by the brachiopods Acanthorhynchia multistriata and Somalithyris lakhaparensis, but most taxa are bivalves, among them several large forms such as Megacuccullaea eminens, Radulopecten moondanensis, Gervillella aviculoides, and Seebachia (Eoseebachia) sowerbyana. The condensed horizon formed offshore below the storm wave-base. GAB III is a nodular ferruginous mudrock, which is, apart from very rare ammonites, unfossiliferous. The lack of fossils probably is a result of early diagenetic shell dissolution but the alternative explanation, i.e., unfavourable conditions on the sea floor cannot be excluded. GAB I to III are maximum flooding zones of metre- to decametre-scale T-R cycles, but together form the MFZ of a higher rank, probably 3rd-order cycle, the HST of which culminates in thick, coarse-grained sandstones of the early Cretaceous socalled Trigonia Ridge (see also Fürsich and Pandey 2003, fig 4).

(5) Taphonomic and palaeoecological features are useful criteria for recognising condensed units, when used in combination: they help to establish the precise position of such beds along an onshore-offshore transect and the water depth in which they formed. It is, however, clear that such conclusions will be most reliable when incorporating also sedimentological data.

Fig. 17 Section through the middle and upper part of the Jhuran Formation of the southwestern Jara Dome and its sequence stratigraphic interpretation. The section is composed of highly asymmetric transgressive-regressive cycles, Commonly, TST deposits are represented only by the reworked top of the underlying HST 

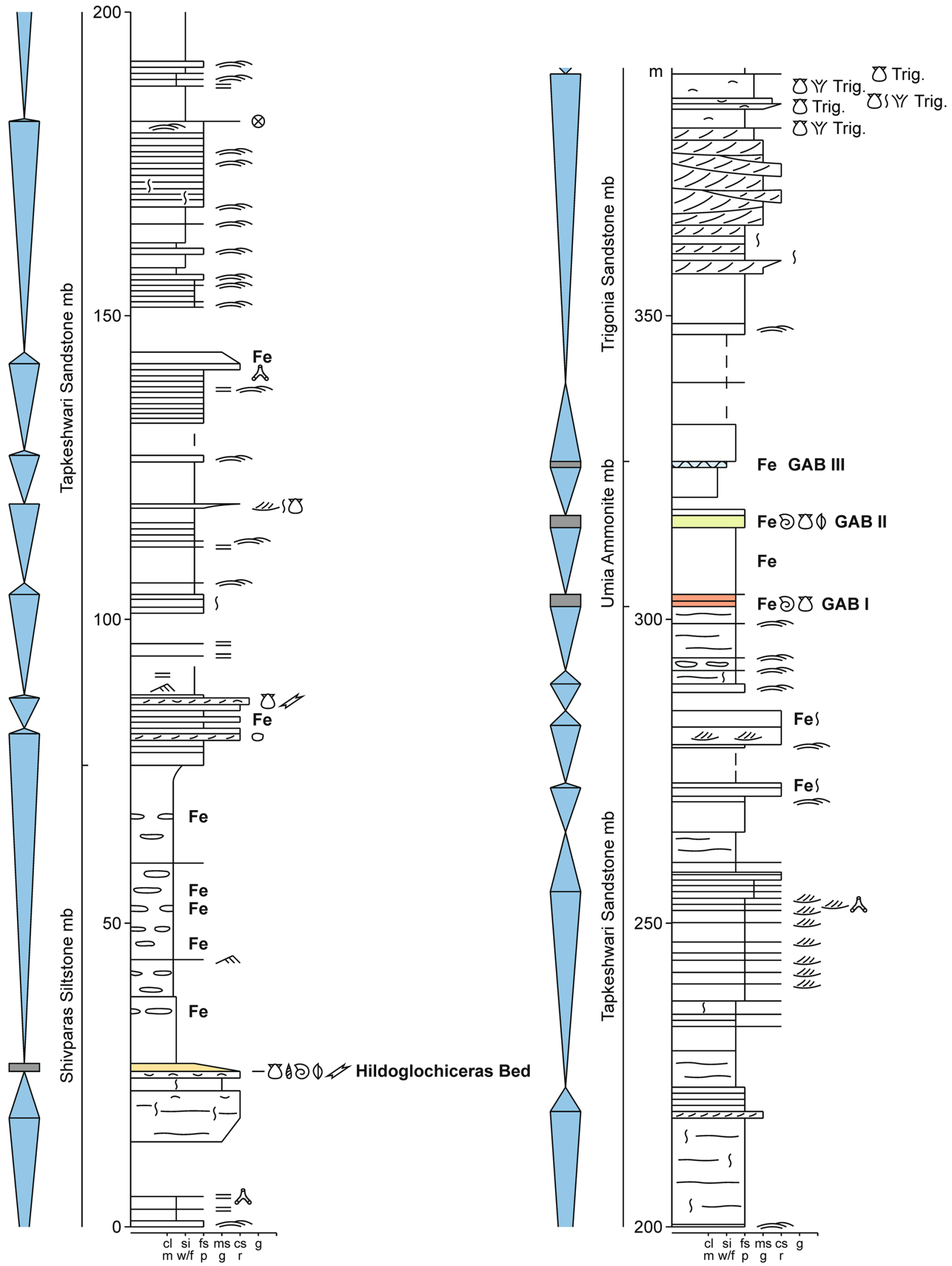
Acknowledgements The localities discussed in this paper were repeatedly visited and sampled during the last 30 years. We thank all those colleagues and students who accompanied us during these visits. In particular, we thank P.H. Bhatti, M. Thakkar, and G. Chauhan, Bhuj, for logistic support, S.A. Bhosale, K. Chaskar (both Bhuj), K. Page (Plymouth), and the late J.H. Callomon (London) for their assistance in the field, and A. Munnecke, Erlangen, M. Wilmsen, Dresden, and U. Basal, Dresden, for useful discussions. DKP is grateful to DST (New Delhi) for financial support (grant \#EMR/2015/001574). MA acknowledges financial support by the German Research Foundation (grant \#AL 1740/3-1). B. Leipner-Mata, Erlangen, produced the thin-sections and W. Ayoub-Hannaa, Erlangen, photographed the specimens. We also thank two anonymous reviewers for their constructive comments.

Funding Open Access funding enabled and organized by Projekt DEAL.

Open Access This article is licensed under a Creative Commons Attribution 4.0 International License, which permits use, sharing, adaptation, distribution and reproduction in any medium or format, as long as you give appropriate credit to the original author(s) and the source, provide a link to the Creative Commons licence, and indicate if changes were made. The images or other third party material in this article are included in the article's Creative Commons licence, unless indicated otherwise in a credit line to the material. If material is not included in the article's Creative Commons licence and your intended use is not permitted by statutory regulation or exceeds the permitted use, you will need to obtain permission directly from the copyright holder. To view a copy of this licence, visit http://creativecommons.org/licenses/by/4.0/.

\section{References}

Abbott ST (1997) Mid-cycle condensed shell beds from the midPleistocene cyclothems, New Zealand: implications for sequence architecture. Sedimentology 44:805-824

Alberti M, Fürsich FT, Pandey DK (2019) Sedimentology of a prograding delta complex: the Jurassic succession of the Wagad Uplift in the Kachchh Basin, western India. N Jb Geol Paläont Abh 292:1-24

Aller RC (1982) Carbonate dissolution in nearshore terrigenous muds: the role of physical and biological reworking. J Geol 90:79-95

Archuby FM, Fürsich FT (2010) Facies analysis of a highly cyclic sedimentary unit: the Late Hauterivian to Early Barremian Agua de la Mula Member of the Agrio Formation, Neuquén Basin, Argentina. Beringeria 41:77-127

Arnott RWC (1995) The parasequence definition - are transgressive deposits inadequately addressed? J Sediment Res B65:1-6

Biswas SK (1980) Mesozoic stratigraphy of Kutch, Gujarat. Quart J Geol Miner Metallurg Soc India 49:1-42 (for 1977)

Biswas SK (2016) Mesozoic and Tertiary stratigraphy of Kutch (Kachchh) - a review. Geol Soc India Spec Publ No 6:1-24

Brett CE (1998) Sequence stratigraphy, paleoecology, and evolution: biotic clues and responses to sea level fluctuations. Palaios 13:241-262

Burkhalter RM (1995) Ooidal ironstones and ferruginous microbialites: origin and relation to sequence stratigraphy (Aalenian and Bajocian, Swiss Jura mountains). Sedimentology 42:57-74

Catuneanu O (2006) Principles of sequence stratigraphy. Elsevier, Amsterdam, p 375

Clement AM, Tacket LS, Ritterbush KA, Ibarra Y (2020) Formation and stratigraphic facies distribution of early Jurassic iron oolite deposits from west central Nevada, USA. Sediment Geol 395:105537

Collin YP, Loreau JP, Courville P (2005) Depositional environments and iron ooid formation in condensed sections (CallovianOxfordian, south-eastern Paris basin, France). Sedimentology 52:969-985

Cummins H, Powell EN, Stanton RJ Jr, Staff G (1986) The rate of taphonomic loss in modern benthic habitats: how much of the potentially preservable community is preserved? Palaeogeogr Palaeoclimatol Palaeoecol 52:291-320

Davies DJ, Powell EN, Stanton RJ Jr (1989) Relative rates of shell dissolution and net sediment accumulation-a commentary: can shell beds form by the gradual accumulation of biogenic debris on the sea floor? Lethaia 22:207-212

Desai BG, Biswas SK (2018) Post-rift deltaic sedimentation in western Kachchh Basin: insights from ichnology and sedimentology. Palaeogeogr Palaeoclimat Palaeoecol 50:104-124

Föllmi KB (2016) Sedimentary condensation. Earth Sci Rev $15: 143-180$

Fürsich FT, Aberhan M (1990) Significance of time-averaging for palaeocommunity analysis. Lethaia 2:143-152

Fürsich FT, Kauffman EG (1984) Palaeoecology of marginal marine sedimentary cycles in the Albian Bear River Formation of southwestern Wyoming. Palaeontology 2:501-536

Fürsich FT, Pandey DK (2003) Sequence stratigraphic significance of sedimentary cycles and shell concentrations in the Upper JurassicLower Cretaceous of Kachchh, western India. Palaeogeogr Palaeoclimatol Palaeoecol 19:285-309

Fürsich FT, Alberti M, Pandey DK (2013) Stratigraphy and palaeoenvironments of Jurassic rocks of Kachchh. Field Guide. Beringeria, Spec Issue 7:3-174

Fürsich FT, Hautmann M, Senowbari-Daryan B, Seyed-Emami K (2005) The Upper Triassic Nayband and Darkuh formations of east-central Iran: Facies patterns and biota of extensional basins on an accreted terrane. Beringeria:53-133

Fürsich FT, Pandey DK, Alberti M, Mukherjee D, Chauhan G (2020) Stratigraphic architecture and palaeoenvironments in the Kachchh rift basin during the Jurassic. In: 36th International Geological Congress, Field Trip Guide WR010, p 143

Heim A (1934) Stratigraphische Kondensation. Eclog geol Helvet 27:372-383

Hryniewicz K, Bakayevaa S, Heneralova L, Hnylko O, Jenkins RG, Kaim A (2020) Taphonomy and palaeoecology of deep-water chemosymbiotic bivalves from the Eocene of Outer Eastern Carpathians, Ukraine. Palaeogeogr Palaeoclimatol Palaeoecol 553:109782

Kidwell SM (1989) Stratigraphic condensation of marine transgressive records: origin of major shell deposits in the Miocene of Maryland. J Geol 97:1-24

Kidwell SM (1991) The stratigraphy of shell concentrations. In: Allison, P.A., Briggs, D.E.G. (eds) Taphonomy: releasing the data locked in the fossil record. Topics in Geobiology 9:211-290

Kidwell SM, Bosence DWJ (1991) Taphonomy and time-averaging of marine shelly faunas. . In: Allison PA, Briggs DEG (eds) Taphonomy: releasing the data locked in the fossil record. Topics in Geobiology 9:115-209

Kidwell SM, Fürsich FT, Aigner T (1986) Conceptual framework for the analysis and classification of fossil concentrations. Palaios $1: 228-238$

Kitchin FL (1903) The Jurassic fauna of Cutch, the Lamellibranchiata; No. 1, Genus Trigonia. Mem Geol Surv India, Palaeont Indica, ser 9, 3(2):1-122

Krishna J (1991) Discovery of Lower Berriasian (Lower Cretaceous) ammonoid genus Argentiniceras from Kachchh (India) and its relevance to Jurassic-Cretaceous boundary. Newsl Stratigr $23: 141-150$ 
Krishna J, Pathak DB, Pandey B (1994) New ammonoid evidence for the Jurassic/Cretaceous boundary in Kachchh western India, and long distance correlation with southern Europe. Geobios Mém Special 17:327-335

Mount J (1985) Mixed siliciclastic and carbonate sediments: a proposed first-order textural and compositional classification. Sedimentology $32: 435-442$

Odin GS, Matter A (1981) De glauconarium origine. Sedimentology 28:611-641

Pandey DK, Alberti M, Fürsich FT, Bhaumik S, Ayoub-Hannaa W (2016) A review of the Tithonian ammonites from the Kachchh Basin, western India. J Palaeont Soc India 61:141-173

Pandey DK, Lathuilière B, Fürsich FT, Sanjeev Kuldeep (2002) The oldest Jurassic cyathophorid coral from siliciclastic environment of the Kachchh Basin, western India. Paläont Z 76:347-356

Rai J, Jain S (2013) Pliensbachian nannofossils from Kachchh: Implications on the earliest transgressive event on the western Indian margin. Zitteliana A 53:105-120

Sharafi M, Mahboubi A, Moussavi-Harami R, Ashuri M, Rahimi B. ((2013) Sequence stratigraphic significance of sedimentary cycles and shell concentrations in the Aitamir Formation
(Albian-Cenomanian), Kopet-Dagh Basin, northeastern Iran. J Asian Earth Sci 67-68:171-186

Stanley SM (2014) Evolutionary radiation of shallow-water Lucinidae (Bivalvia with endosymbionts) as a result of rise of the seagrasses and mangroves. Geology 42:803-806

Taylor AM, Goldring RG (1993) Description and analysis of bioturbation and ichnofabric. J Geol Soc Lond 150:141-148

Van Wagoner JC, Posamentier HW, Mitchum RM, Vail PR, Sarg JF, Loutit TS, Hardenbol J (1988) An overview of sequence stratigraphy and key definitions. In: Wilgus CK, Hastings BS, Kendall CGStC, Posamentier HW, Ross CA, Van Wagoner JC (Eds), Sea Level Changes - An Integrated Approach. Soc Econ Paleont Miner Spec Publ 42:39-45

Wilmsen M, Niebuhr B, Janetschke N (2014) Sea-level changes across the Lower-Middle Turonian boundary: evidence from borehole BKS 7/91 (Danubian Cretaceous Group, Bavaria, Germany). Z Deutsch Ges Geowiss 165:641-654

Young TP (1989) Phanerozoic ironstones: an introduction and review. In: Young TP, Taylor WEG (eds) Phanerozoic Ironstones. Geol Soc Spec Publ 46:ix-xxxv 